\title{
Modelling human prostate cancer: rat models
}

Elisabete Nascimento-Gonçalves ${ }^{1}$, Ana I. Faustino-Rocha ${ }^{2,3}$, Fernanda Seixas ${ }^{1,4}$, Mário Ginja $^{1,2}$, Rita Ferreira ${ }^{5}$, Margarida Fardilha, Paula A. Oliveira ${ }^{1,2}$

${ }^{1}$ Department of Veterinary Sciences, University of Trás-os-Montes and Alto Douro (UTAD), Vila Real, Portugal

2 Center for the Research and Technology of Agro-Environmental and Biological Sciences (CITAB), UTAD, Vila Real, Portugal

3 Faculty of Veterinary Medicine, Lusophone University of Humanities and Technologies, Lisbon, Portugal

${ }^{4}$ Animal and Veterinary Research Center (CECAV), UTAD, Vila Real, Portugal

${ }^{5}$ Organic Chemistry, Natural Products and Foodstuffs (QOPNA), Mass Spectrometry Center, University of Aveiro (UA), Aveiro, Portugal

${ }^{6}$ Laboratory of Signal Transduction, Institute for Research in Biomedicine, Medical Sciences Department, UA, Aveiro, Portugal.

Corresponding author: Paula A. Oliveira, CITAB, Department of Veterinary Sciences, UTAD, 5001-911, Vila Real, Portugal

Fax number 00351259350480, phone number 00351259350651, e-mail address pamo@utad.pt

Word count: 4838

Figures: 4

Tables: 5 


\section{Abstract}

Prostate cancer is the second most common cancer in men, affecting approximately 1.1 million men worldwide. In this way, the study of prostate cancer biopathology and the study of new potential therapies is of paramount importance. Several rat models were developed over the years to study prostate cancer, namely spontaneous models, chemically-induced models, implantation of cancer cell lines and geneticallyengineered models. This manuscript aimed to provide the readers with an overview of the rat models of prostate cancer, highlighting their advantages and disadvantages, as well as, their applications.

Keywords: animal models, image monitoring, prostate carcinogenesis, rats 


\section{Introduction}

Prostate cancer is the second most common cancer in men, affecting approximately 1.1 million men worldwide. In the year 2012, prostate cancer was responsible for 307 , 000 deaths, being considered the fifth leading cause of death from cancer in men [1]. Although the causes of prostate cancer are not fully understood, many risk factors have been considered for the development of this type of cancer, such as age, race, family history, diet, hormone exposure, particularly to androgens and estrogens, and inflammation [2-4]. Since the prostate gland is an androgen-dependent tissue and consequently the prostate cancer is also androgen-dependent [2,3], the important role of androgenic hormones for prostate cancer development is well recognized [4].

Animal models have been used to study several diseases, like cancer, cerebral palsy, diabetes, Alzheimer, obesity and cardiac disease. The animal models may contribute invaluable information to better understand many aspects involved in disease development, and for the discovery and development of new pharmacological and non-pharmacological therapies (lifestyle) and preventive strategies, which may then be tested in clinical trials.

The animal models may be spontaneous, chemically-induced, transgenic/mutant animals with modifications in targeted genes, or implanted models (syngeneic or xenograft) [5-8]. An ideal animal model of human disease should be simple, not expensive and mimics the Human disease as much as possible. The rodents are commonly used in experimental research as cancer models, because they are relatively easy and cheap to maintain, their physiology and genetics are well known, they are mammals like Humans and the tumor's development is fast (all steps of carcinogenesis - initiation, promotion, progression and metastasis - may be observed) $[6,8]$. 
This review focused on rat prostate cancer models that have been established over the years for prostate cancer study, highlighting their advantages and disadvantages, as well as, their applications. We also describe the works performed in these prostate cancer models for the evaluation of several drugs and natural compounds.

\section{Rat prostate: anatomy and histology}

Prostate is an accessory gland of the reproductive system of male mammals, found below the bladder in front of the rectum. Despite analogies found in prostate morphogenesis in different species, the variability of its anatomy among mammals is remarkable. While the prostate is a compact solitary structure in men and dogs, the prostate of rats and mice consists of distinct lobes. The rat prostate consists of four distinct lobes: the ventral, lateral, dorsal and anterior lobes, according to their relative position to urinary bladder [2,9] (Fig. 1). Each lobe has different morphological characteristics. The ventral lobe, unlike the others, does not have a human homologue, and consists of two discrete lobes ventro-lateral to the urinary bladder and attached to the urethra by connective tissue; the dorso and lateral lobes, commonly referred as dorsolateral prostate, are located along the urethra, forming a macroscopic mass. The anterior lobes are thin tubular structures attached to the seminal vesicles [10]. The knowledge of the different rat prostate lobes is important, because the ability to develop carcinomas vary among them [2]. The man prostate is a walnut-sized gland located beneath the urinary bladder and it is just one tubulealveolar gland [11]. Despite these anatomical differences, recent studies found similarities in the molecular mechanisms underlying prostate cancer development in rats and men, making the rat as a valid animal model to study human prostate cancer. 


\section{Rat as a model of prostate carcinogenesis}

Despite many research projects in the field of prostate cancer are carried out using cells lines (in vitro studies), which allow the understanding of biological aspects related to the development of this disease, they fail to mimic the complex cellular interaction that occurs in tumor microenvironment. To overcome this limitation, researchers employed their efforts for several years on the development of animal models to study this disease.

In 1937, Moore and Melchionna were the first ones to induce prostate carcinoma in the anterior lobe of the White rat prostate through the direct injection of 1:2 benzpyrene into prostate [12]. Metastasis development was not reported in this model, being considered a model limitation. Some years later, in 1945, Dunning and colleagues, induced the development of metastasizing prostate carcinomas in albino Fisher 344 rats and black agouti Irish AxC 9935 rats [13], through the implantation of methylcholanthrene crystal into prostate. Since then, several experimental researches were conducted to discover chemical carcinogenesis with tropism for prostate tissue [14]. Highlight the N-nitrosobis (2-oxopropyl) amine (BOP) discovered in 1981 by Pour [15], the N-Methyl-N-nitrosourea (MNU) discovered in 1986 by Pollard [9], the 3,2'dimethyl-4-aminobiphenyl (DMAB) discovered in 1986 by Katayana [16] and the 2amino-1-methyl-6-phenylimidazol[4,5-b]pyridine (PhiP) discovered in 1997 by Shirai [17].

An adequate rat model of prostate carcinogenesis should develop androgen-sensitive adenocarcinomas in a short period of time, mimic the physiology and characteristics of man tumors, and the tumors must metastasize, preferably to bones. The tumor 
development should be from dorsal, lateral or anterior prostate lobes that are human homologue [14].

Concerning chemical inducers, several chemical and natural compounds may be used to assess their effect on prostate carcinogenesis. Among the agents used are: lycopene [18], dehydroepiandrosterone (DHEA) [19], fluasterone [20], quercetin [21], zinc [22], vitamin E [23], selenium [24], celecoxib [25], flutamide [26], cadmium [27], pioglitazone [28], pomegranate [29,30] and cholesterol [31].

\section{Rat models of prostate carcinogenesis}

Several animal models are available for the study of prostate cancer: spontaneous tumors, chemically or hormonally-induced, implantation of cancer cells and genetically engineered animals [2,32].

\subsection{Spontaneous tumors}

The first report of prostate spontaneous tumor was in 1963 by Dr. W.F. Dunning, who detected a single adenocarcinoma without metastasis in a 22 months-old Copenhagen rat [33-35]. Later, in 1973, Pollard reported spontaneous prostatic carcinomas in dorso-lateral and anterior prostate lobes, in a germfree Wistar rats with 26 months of age [34]. In 1957, spontaneous tumors of the ventral prostate were reported in 34-37 months-old $\mathrm{AxC}$ rats [33]. Aging male, on average 24 months, $\mathrm{ACl} / \mathrm{Seg}$ rats demonstrated high susceptibility to develop spontaneous ventral prostate adenocarcinomas [36]. Since a long latency period is needed for tumor development (around 2-3 years) and tumor incidence is low, these spontaneous tumors are not advantageous as animal models [32]. 


\subsection{Induced tumors}

The prostate tumors development may be easily induced through the administration of chemical carcinogens alone or by the combination of chemical carcinogens and hormones [2].

\subsubsection{Chemically-induced prostate cancer}

Up to now, four chemical compounds are recognized for the induction of prostate carcinomas development in rats: BOP, MNU, DMAB and PhiP [2].

\subsubsection{N-nitrosobis (2-oxopropyl) amine (BOP)}

The BOP belongs to the family of nitrosamines and it acts as a potent carcinogen in different species and organs, like hamsters (pancreatic tumors) $[37,38]$ and guinea pigs (biliary and hepatic neoplasms) [39]. When ingested by the animals, this compound is converted into carbon dioxide becoming a DNA methylating agent. BOP is also converted in two nitrosamine metabolites, N-nitrosobis (2-hydroxypropyl)amine (BHP) and N-nitroso(2-hydroxypropyl)(2-oxopropyl)amine (HPOP) [38,40]. In 1981, Pour [15] reported for the first time that application of BOP induced tumors in the prostate dorsal lobe in MRC rats. Some years later, the same author conducted a study to evaluate the effects of dietary fat on the development of prostatic cancer in Wistarderived MRC rats: testosterone propionate $(100 \mathrm{mg} / \mathrm{kg}$ of body weight, subcutaneous injection) was daily administered for five days, and BOP $(20 \mathrm{mg} / \mathrm{kg}$ body weight subcutaneous injection) was daily given to rats for three days, beginning with the third testosterone injection. This study lasted 72 weeks and showed that dietary fat did not influence the patterns of prostatic cancer [41]. Despite this, the BOP only induced 
squamous cell carcinomas development in the ventral prostate lobe, the only lobe that does not have a human homologue, making it an animal model not widely used [14].

\subsubsection{N-methyl-N-nitrosourea (MNU)}

The MNU is a nitro-compound that acts as direct carcinogen agent by methylation of the guanine nucleosides without previous metabolic activation [42,43]. Pollard developed a chemically and hormonally-induced prostate cancer model in LoboundWistar rats through the administration of MNU associated with hormonal treatment $[2,9]$. This model consists of an intravenous injection of $\mathrm{MNU}(30-40 \mathrm{mg} / \mathrm{kg})$, followed by a long-term administration of testosterone $(10-40 \mathrm{mg})$ via silastic implants [9]. The tumors developed within a year in the dorsolateral prostate, showing invasive growth and metastases to the lymph nodes and lungs [9]. Over the years, this model was improved and now the sequential treatment with an antiandrogen (cyproterone acetate or flutamide), followed by a single intravenous or intraperitoneal injection of MNU and chronic treatment with silastic implants filled with testosterone is frequently used for prostate cancer development $[9,44,45]$. This approach leads to a high incidence of carcinomas in various rat strains [14]. Maarten Bosland described this method in detail: cyproterone acetate $(50 \mathrm{mg} / \mathrm{kg} / \mathrm{day})$ may be administered by gavage as suspension in water, or by subcutaneous injection in oil, during 2-3 weeks, followed by the administration of testosterone propionate $(10-100 \mathrm{mg} / \mathrm{kg})$ by subcutaneous injection during three consecutive days. Forty-eight hours later, MNU must be administered by intravenous or intraperitoneal injection in doses between 30 to 50 $\mathrm{mg} / \mathrm{kg}$, and finally, testosterone propionate in silastic implants are placed subcutaneously in interscapular region by surgical approach under general anesthesia 
[46]. This method, although complex in execution, allows a higher incidence of rat prostate cancer. To achieve the maximal tumor incidence, the experimental work should be conducted until 50-60 weeks after MNU injection [9]. Over the years many authors used this method to study prostate carcinogenesis [47].

The animal models of chemically-induced prostate cancer makes possible the evaluation of the chemopreventive effect of different compounds. Chemoprevention may be defined as the use of natural, synthetic or biological agents to reverse, suppress or prevent initial phases of carcinogenesis or progression of malignant cells to invasive disease $[32,48]$. The studies may be consulted in Table 1.

\subsubsection{3,2'-dimethyl-4-aminobiphenyl (DMAB)}

The DMAB is a classical polycyclic aromatic hydrocarbon with carcinogenic properties for multiple organs, such as colon, urinary bladder, mammary glands and Zymbal glands [2]. This compound needs to be previously activated in the liver. Then, the metabolites may be also metabolized and their oxidation products interact with DNA causing transversions in nucleotides, inducing irreversible changes [49]. The ability of $D M A B$ to induce the development of carcinomas in ventral prostate lobe was reported by Katayama in 1986 [50] and confirmed by other authors over the years. The carcinogenic potential of DMAB is dose-depend. It was demonstrated that a low dosage of DMAB given over a long period (around 48 weeks) was more effective to induce prostate cancer development when compared with a high dosage over a short period of time (10-25 weeks) [51]. High doses of testosterone propionate may be used to promote induction of invasive carcinomas in the dorso-lateral and anterior prostate lobes $[2,52]$. The rat strains have different susceptibilities to DMAB, F344 and ACl rat 
strain are more susceptible, while Wistar and Sprague-Dawley rats are resistant strains [53]. The DMAB method consists of a subcutaneous administration, normally at dose of $50 \mathrm{mg} / \mathrm{kg} /$ body weight, 10 times at 2-week intervals [52]. Silastic tubes filled with testosterone propionate may be used to promote tumor development. The implants should be placed subcutaneously and replaced at 6-week intervals [54]. In a general way, chemopreventive studies with this compound last 60 weeks, on average [55]. More details may be consulted in Table 2 .

\subsubsection{2-amino-1-methyl-6-phenylimidazol[4,5-b]pyridine (PhiP)}

The PhiP is a heterocyclic amine isolated from cooked fish and meat. This compound may be metabolized to biologically active metabolites (N-hydroxy-PhIP and N-acetoxyPhIP) that form DNA adducts [56-58] and induce cancer development in mammary gland, intestine and prostate $[59,60]$. Prostate cancer histopathological features are similar to those induced by DMAB. The rats exposed to PhiP develop prostate carcinomas in the ventral lobe, but not in the dorsolateral or anterior lobes. The experimental protocols using PhiP as prostate carcinogen consists of the administration of this compound mixed into the diet $[32,59]$ or administrated intragastrically by gavage $(70-200 \mathrm{mg} / \mathrm{kg})[56,61,62]$. This model can be used for chemoprevention studies. Detailed information concerning to these studies may be consulted in Table 3.

\subsubsection{Hormonally-induced prostate cancer}

Since the rat prostate is an androgen-sensitive tissue, the administration of testosterone may induce the development of invasive adenocarcinomas in dorso- 
lateral and in anterior prostate, with low incidence in various rat strains $[9,14,32]$. The association of testosterone with estrogen, like $17 \beta$-estradiol, induces a higher carcinoma incidence in the dorsal, lateral and anterior prostate in Noble and SpragueDawley rats [14]. The methodology to induce prostate tumors with this compound consist of the use of silastic tubes filled with testosterone (crystalline testosterone or testosterone propionate) alone or in combination with estradiol (in two silastic tubes separated) implanted under the skin [14]. The wall thickness determines the speed of hormone release, as well as, the length of the tubing over which the hormone can diffuse out. The amount of the hormone in silastic tubes determine the duration of release. This model may be used in chemopreventive studies [63-65], but it is not very advantageous because of the early death of the rats due to the concomitant development of estrogen-induced pituitary tumors, which prevent the prostate carcinomas from growing and metastasis [14].

\subsection{Implantation of cancer cell lines}

Prostate cancer cells lines may be implanted in rats for tumor development. The cell lines may be either obtained from human prostate tumors and implanted into rats (xenograft model) [66], or obtained from chemically-induced or spontaneous rat prostate cancer (syngeneic model) [67-71]. Furthermore, these models may be orthotopic, if the prostate cancer cells are implanted in the tumor site of origin, in this case the prostate [72-74]; or heterotopic, if the cancer cells are implanted in a different place, for example subcutaneously [68] or in subcutis of the dorsal surface of the rat tail [71]. 
PAlll cancer cell line is an example of syngeneic model. This androgen insensitive cancer cell line is derived from a spontaneous prostate carcinoma from a LobundWistar rat and it has the ability to form large primary tumors when injected subcutaneously $[68,75]$. Harvey Pollard and colleagues [68] used this model to test the influence of ascorbic acid on tumorigenesis and concluded that pharmacological doses of this compound may suppress tumor growth and metastasis. PLS 10 is another cancer cell line, it was established from DMAB plus testosterone-induced carcinomas in the dorsal prostate of male F344 rats, which may be implanted into rats [67]. The PSL10 cell line was used as a syngeneic heterotopic model into the flank of F344 rats in a study aiming to understand hyperthermic effects of magnetic particles on rat prostate cancer. The authors concluded that hyperthermia is an effective therapy for prostate cancer [67].

The xenograft prostate cancer models in rats are not widely used in experimental research due to the few immunodeficient rat strains available for use. Highlight the work of Tumati [66] that developed an advanced orthotopic prostate cancer model using a modified human prostate cancer cell line (PC3) implanted into the prostate of nude or Copenhagen rats to assess the effects of high-dose image-guided radiation therapy combined with biological agents [66]. In another work, Andressen [76] used immunodeficient male homozygous Sprague-Dawley rats injected with CRW22 human prostate cancer cell line to investigate the ability to induce bone metastasis.

\subsubsection{Dunning model}

Most of the in vivo rat tumor lines for testing new drugs for the treatment of hormonedependent prostate cancers originated from the Dunning R3327 adenocarcinoma of 
the Copenhagen rat. This cell line was developed from a spontaneous dorsal prostatic adenocarcinoma in a Copenhagen male rat in 1963. The tumor was identified in a necropsy and grafts of the tumor were transplanted into syngeneic rats and $F_{1}$ hybrids of a Copenhagen $x$ Fischer cross. The transplanted tumor was histologically, biochemically and biologically similar to the rat dorso-lateral prostate [35]. Since then, several sublines were developed from Dunning R3327, such as AT-1, MAT-Ly-Lu, AT-4R3327-5 and PAP [35]. Each subline has different characteristics and exhibits a range of phenotypes that mimic aspects of the man prostate cancer, like the slow-growing androgen-responsive tumor [7]. These cell lines may be passed in vivo without lose tumorigenicity and metastatic ability [35]. Since the tumor associated with this model is slow-growing, non-metastatic, androgen-responsive, and maintained the histologic appearance and biochemical properties of the rat dorsal prostate gland, it is considered an appropriate model for cancer research, namely for chemoprevention studies [35] (Table 4).

The Dunning model has the main advantage of not requiring exposure to chemical compounds for its execution, thus reducing the health risk for the investigator, the environmental effects and costs.

\subsection{Genetically-engineered models}

Both chemically or hormonally-induced prostate cancer models are labor intensive and need a long period of latency for tumor development: at least 60 weeks for the DMAB and PhIP models, 50 weeks for the MNU models, 70 weeks for BOP models and 40 weeks for hormonally-induced models on average. As an attempt to overcome this disadvantage, genetically-engineered models were developed [77,78]. In 2001, Shirai 
and colleagues created a transgenic rat prostate cancer model, named "transgenic rat with adenocarcinomas of the prostate (TRAP)", using the probasin gene promoter and the Simian Virus-40 T (SV40-T) antigen in the genetic background of Sprague-Dawley rats. The rat probasin gene encodes prostate-specific proteins, while androgen and zinc regulates specific proteins to the dorsolateral epithelium of the prostate. The prostate tumors developed by this animal model are androgen-receptor positive and androgen-dependent [78], and develop mostly in the ventral, lateral and dorsal prostate lobes at high incidence $[32,78]$. The initial lesions in prostate epithelial cells may be observed at four weeks and the carcinomas become extensive at 15 weeks [32], providing a useful animal model to investigate the mechanisms underlying prostate cancer development, as well as, the effects of modifying factors. Another transgenic rat prostate cancer model was developed in the Lewis rat, crossing the Sprague-Dawley SV40-T rats with Lewis strain to study prostate cancer immunotherapy (Table 5). The prostate tumors developed with $100 \%$ penetrance and were androgen sensitive [79].

\section{Follow-up of animal models - prostate imaging}

Although the prostate cancer remains the fifth cause of death by cancer among men, the mortality associated with this type cancer has decreased in the past decades, mainly due to the widespread use of screening strategies. Despite the only definitive way to confirm prostate cancer is through a prostate biopsy (frequently ultrasound guided biopsy) [80], screening for this kind of cancer includes digital rectal examination (DRE) focused on prostate size and consistency, or more typically, a change on serum prostate-specific antigen (PSA) [81]. Furthermore, the prostate changes may be non- 
invasively evaluated through imaging modalities, such as ultrasonography (transrectal ultrasound) [82]. Nowadays, ultrasonography provides not only anatomic information (prostate dimensions and macroscopic structure of parenchyma) through the use of Bmode (grayscale ultrasonography) [66,83], but also functional information on tumor microenvironment (evaluation of prostate vascularization) through the use of Power Doppler, Color Doppler, Pulsed Doppler, B Flow, and ultimately contrast agents. Contrast-enhanced ultrasound (CEUS) is based on the intravenous administration of a contrast agent [80] and allows not only to quantify and evaluate the pattern of distribution of the vessels inside the parenchymal prostate (tortuous vessels, centripetal/centrifugal enhancement of contrast agent), but also to perform dynamic studies, evaluating the arrival time of the contrast agent, peak intensity, time to peak, ascending-slope, descending-slope and area under the curve [84].

When compared with other imaging modalities, the ultrasonography has some advantages, namely the ultrasound apparatus are portable, they are less expensive, they are recommended for claustrophobic patients and, the most important one, does not impose ionizing radiation. Although the ultrasonography is the oldest and the most widely used imaging modality for prostate imaging [80], it is limited on the detection and location of prostate cancer, and on the tissue contrast between benign and cancerous tissues due to its lower sensitivity and specificity [82]. To overcome these limitations, other imaging modalities, such as Magnetic Resonance Imaging and Positron Emission Tomography have been employed on prostate screening. Magnetic Resonance Imaging allows the visualization of the prostate contours and internal anatomy, providing functional and structural information of tumor vasculature and physiology [84] with great sensitivity, but with low specificity [85]. This imaging 
technique is usually combined with other techniques, like Diffusion Weighted Imaging that improves the detection and localization of prostate cancer; Magnetic Resonance Spectroscopy that assesses the relative concentration of different chemical compounds in tissue, and Dynamic Contrast-Enhanced Magnetic Resonance imaging whose principles are based on tumor angiogenesis $[85,86]$. Positron Emission Tomography is a non-invasive imaging modality that uses radiolabel tracers and gamma cameras to measure sensitively and quantitatively the concentration of these radioactive molecules in the prostate [84]. This imaging modality is often combined with Magnetic Resonance Imaging for anatomical localization of the spots for radiotracers [80]. Positron Emission Tomography is more used in later stage cancer than in diagnosis, being useful on the detection of biochemical relapse, cancer recurrence [80] and metastasis. This imaging modality has the disadvantages of not detect small lesions, not distinguish benign and malignant processes, the higher costs, and requirement of advanced training and skills [87]. It is worth to note that these imaging modalities may also be used in rat models for prostate cancer diagnosis and to monitor the effects of new potential therapies for cancer treatment [88], however the published works are scarce.

Our research team has some ultrasonographic, Magnetic Resonance Imaging and Computed Tomography studies on the rat model of prostate cancer. The effects of long-term exercise training on prostate carcinogenesis were studied using a chemically and hormonally-induced rat model. For this, a multistep experimental protocol was employed using Wistar rats. At 12 weeks of age, the experimental protocol was initiated with the subcutaneous administration of the anti-androgenic drug flutamide (50 mg/kg of body weight) for consecutive 21 days. Twenty-four hours after the last 
flutamide administration, they received a subcutaneous injection of testosterone propionate at a dose of $100 \mathrm{mg} / \mathrm{kg}$ of body weight, followed by a single intraperitoneal administration of the carcinogen agent $\mathrm{MNU}$ ( $30 \mathrm{mg} / \mathrm{kg}$ of body weight) $48 \mathrm{~h}$ after the testosterone administration. Finally, two weeks after the MNU administration, testosterone filled tubes were subcutaneously implanted on the cervical region under anesthesia, and remained until the end of the experiment. The prostate dimensions and macroscopic appearance was non-invasively monitored throughout the experimental protocol by ultrasonography using a $12 \mathrm{MHz}$ linear probe. The preliminary results showed a reduction of prostate volume after the flutamide administration (more evident on ventral lobes) (Fig. 2A and B). An inverse effect was observed six weeks after the MNU administration, with the carcinogen promoting the increase of prostate volume (with higher incidence on ventral lobes) and compressing the neck of urinary bladder (Fig. 2C and D). The prostate volume continued increasing overtime, until the end of the experimental work, with a marked volume enhancement of dorsal prostate lobes and the vesicular glands placed near the prostate lobes (Fig. 2E and F). We also performed a study of prostate vascularization using Power Doppler, B Flow and contrast-enhanced ultrasound. An increase on prostate vascularization was observed between the 35 weeks and 61 weeks after MNU administration. Some Magnetic Resonance Imaging and Computed Tomography studies were also performed in normal and cancerous prostates (Fig. 3).

\section{Sample collection and histological evaluation}

A standardized protocol to collect prostate tumors was not yet established. Some researchers remove accessory sex glands together with urinary bladder and separate 
the different prostate lobes from urinary bladder after fixation in formalin $[19,63,89]$.

Other researchers remove the accessory sex glands, fix them in formalin and cut them into slices (where include urethra and seminal vesicles) to paraffin inclusion $[27,31,62,90,91]$. Bosland suggests that the accessory sex glands are best removed and fixed together with urinary bladder and then they should be separated [9]. According to our experience, this seems to be the most appropriate method to identify the different prostate lobes.

\section{Spectrum of prostate lesions}

As mentioned elsewhere, cancer is a multifactorial disease and factors that are responsible for prostate tumorigenesis remain largely unknown. As prostate gland is an endocrine-responsive tissue, many studies focused on the effect of androgens, estrogens and their metabolites on prostate tissues.

Over the years, several rat prostate models using chemical carcinogens have been established. In 1977, Fingerhut and Veenema [92] reported carcinomas induced by DMBA in gonadectomized animals. Later in 1983, Pour described hyperplastic and metaplastic lesions, and squamous cell carcinomas, on MCR rat ventral prostate after repeated BOP administration [93]. These lesions in the ventral prostate, which has no homologue in humans $[36,94,95]$, occur spontaneously in some rat strains, especially in old animals, while chemical carcinogens induce neoplastic changes predominately in the dorsolateral lobe $[96,97]$.

Carcinomas in situ of the dorsolateral prostate (an embryological homologous to the human prostate), were reported in other chemical induction models using DMABP [16] or a combination of DMABP and ethinyl estradiol [98]. Carcinomas of the dorsolateral 
prostate were also described by Pollard and Luckert (1986) on the Lobund-Wistar rat, after a single MNU administration [99].

Bosland and Prinsen (1990) [95] using MNU or DMBA, following chemical castration and testosterone propionate pretreatment, induced invasive adenocarcinomas and carcinomas in situ of the dorsolateral prostate on Wistar rats, 63 weeks after carcinogen injection, mainly in the MNU treated animals. They also reported reactive hyperplasia of the dorsolateral prostate associated with acute and chronic inflammatory processes as a common finding in all experimental group. Apparently, reactive hyperplasia is a consequence of inflammation $[100,101]$.

Later in 1998, McCormick and colleagues [102] reported a high incidence of accessory sex glands cancer, mostly in dorsolateral and anterior prostate lobes, in rats treated sequentially with MNU and testosterone, but lower cancer incidence in rats receiving only MNU or treated with testosterone only; no lesions were observed in untreated animals, suggesting that carcinogenesis depends on both chemical and hormonal stimulation.

In 1999, Rao et al. [19] also described dorsolateral and anterior prostate carcinomas in Wistar-Unilever rats using cyproterone acetate and testosterone propionate, followed by a single dose of MNU in animals with chronic androgen stimulation. They also reported that some animals developed seminal vesicle tumors. Previously, Lucia et al. (1995) [91] reported a high incidence of seminal vesicle tumors, rather than prostate tumors, induced by MNU and testosterone propionate in Lobund-Wistar rats. More recently, in 2014, Bosland [46] reported a high frequency of prostate carcinomas after MNU injection in rats with subcutaneous testosterone implants. The frequency was lower in rats exposed to testosterone alone (not exposed to MNU) and tumors did 
not occur in rats given MNU or not treated. Based on these findings, Bosland [46] suggested that testosterone is a carcinogen and a tumor-promoting agent.

Our group studied the influence of chemical carcinogen and hormonal stimulation on the induction of prostate cancer on Wistar rats using a multistep experimental protocol where the animals were submitted to a chemical castration through the administration of flutamide, followed by the administration of testosterone propionate, a single injection of the carcinogen $\mathrm{MNU}$ and a chronic exposure to testosterone using subcutaneous implants. Twenty-three weeks after the beginning of the experiment, we observed mainly prostate hyperplastic lesions, and occasionally low grade dysplastic lesions, mostly in dorsolateral prostate, which also showed acute inflammation of the acini, focal necrosis and reactive hyperplasia, with small focal areas of chronic stromal inflammation. In fact, all groups of the experiment showed acute and/or chronic inflammation. Inflammation was also frequently reported by other studies $[96,101]$ and reported as more common and severe in the dorsolateral prostate [101], as we observed. Some animals also developed atypical hyperplasia of anterior prostate and seminal vesicle (Fig. 4).

Rats sacrificed 49 weeks after the beginning of the study showed more commonly dysplasia, in situ carcinoma or invasive carcinomas. Our data suggest that chronic exposure to testosterone acts as a tumor promoter in cells initiated by $\mathrm{MNU}$, fostering the transition from hyperplasia to dysplasia and finally the progression from in situ to invasive carcinoma, being this promoter effect apparently time-dependent.

\section{Conclusions}


Experimental data concerning to the rat models of prostate carcinogenesis was reviewed in this work. Although several animal models are available to study prostate cancer and a perfect model does not exist, they provide an important tool to study human and animal prostate carcinogenesis, and to evaluate the effects of potential preventive and therapeutic strategies. The model should be chosen by the researchers, taking into account the aims of their studies, the costs, and the advantages and disadvantages of each one.

Although complex, time-consuming and labor-intensive, the model of prostate cancer hormone and chemically-induced in male rats is the most frequently used due to its advantages when compared with the remaining models. When applying the sequential treatment with an anti-androgen, the carcinogenic agent MNU and the chronic treatment with silastic implants filled with testosterone, a high incidence of prostate carcinomas is observed in several rat strains, with the maximal incidence reached 5060 weeks after the carcinogen administration. Furthermore, the carcinogenesis process may be non-invasively monitored using different imaging modalities, and the tumors developed by the animals are hormone-dependent and histologically similar to those developed by men, allowing the translation of the results from animals to humans.

Acknowledgments: This work was supported by European Investment Funds by FEDER/COMPETE/POCI - Operational Competitiveness and Internationalization Programme, under Project POCI-01-0145-FEDER-006958 and National Funds by FCT Portuguese Foundation for Science and Technology, under the project 
UID/AGR/04033/2013, the project PTDC/DES/114122/2009 and the project PTDC/DTPDES/6077/2014.

Conflict of interest: None to declare.

\section{References:}

[1] Globocan. Estimated Incidence, Mortality and Prevalence Worldwide in 2012, Int. Agency Res. Cancer (Word Heal. Organ. (n.d.).

[2] T. Shirai, S. Takahashi, L. Cui, M. Futakuchi, K. Kato, S. Tamano, K. Imaida, Experimental prostate carcinogenesis - Rodent models, Mutat. Res. - Rev. Mutat. Res. 462 (2000) 219-226. doi:10.1016/S1383-5742(00)00039-9.

[3] M. Bosland, A perspective on the role of estrogen in hormone-induced prostate carcinogenesis, Cancer Lett. 334 (2013) 28-33.

[4] M.C. Bosland, N. Ozten, J. Eskra, A. Mahmoud, A Perspective on Prostate Carcinogenesis and Chemoprevention, Curr Pharmacol Rep. 1 (2015) 258-265.

[5] V.E. Steele, R.A. Lubet, The Use of Animal Models for Cancer Chemoprevention Drug Development, Semin Ocology. $37 \quad$ (2010) 327-338. doi:10.1053/j.seminoncol.2010.05.010.The.

[6] M.S. Lucia, D.G. Bostwick, M. Bosland, A.T. Cockett, D.W. Knapp, I. Leav, M. Pollard, C. Rinker-Schaeffer, T. Shirai, B.A. Watkins, Workgroup I: rodent models of prostate cancer, Prostate. 36 (1998) 49-55.

[7] D. Lambe, L. Zhang, Challenges in Prostate Cancer Research: Animal Models for Nutritional Studies of Chemoprevention and Disease Progression, J. Nutr. 135 (2005) 3009-3015.

[8] D.J. Fagundes, M.O. Taha, Modelo animal de doença: critérios de escolha e espécies de animais de uso corrente, Acta Cirúrgica Bras. 19 (2004) 59-65. doi:10.1590/S0102-86502004000100010.

[9] M.. C. Bosland, Chemical and hormonal induction of prostate cancer in animal models., Urol. Oncol. 2 (1996) 103-110.

[10] C.J. Jesik, J.M. Holland, C. Lee, An anatomic and histologic study of the rat prostate, Prostate. 3 (1982) 81-97. doi:10.1002/pros.2990030111.

[11] B.G. Timms, Prostate development: A historical perspective, Differentiation. 76 (2008) 565-577. doi:10.1111/j.1432-0436.2008.00278.x. 
[12] R.A. Moore, R.H. Melchionna, Production of Tumors of the Prostate og the white rat with 1:2-Benzpyrene, Am. Assoc. Cancer Res. Journals. 30 (1937) 731-741.

[13] W.F. Dunning, M.R. Curtis, A. Segaloff, Methylcholanthrene Squamous Cell Carcinoma of the Rat Prostate with Skeletal Metastases, and Failure of the Rat Liver to Respond to the Same Carcinogen, Cancer Res. (1946) 256-263.

[14] M.C. Bosland, D. Ph, Animal Models for the Study of Prostate Carcinogenesis, 98 (1992) 89-98.

[15] P.M. Pour, A new prostatic cancer model: systemic induction of prostatic cancer in rats by a nitrosamine., Cancer Lett. 13 (1981) 303-8.

[16] S. Katayama, E. Fiala, B.S. Reddy, A. Rivenson, J. Silverman, G.M. Williams, J.H. Weisburger, Prostate adenocarcinoma in rats: induction by 3,2'-dimethyl-4aminobiphenyl., J. Natl. Cancer Inst. 68 (1982) 867-73.

[17] T. Shirai, S. M, T. S, S. Takahashi, H. M., F. M., R. Hasegawa, K. Imaida, M. K., W. K., S. T., N. Ito, The prostate: a targel for carcinogenicity of 2-amino-1-methyl-6phenylimidazo[4,5-b]pyridine (PhIP) derived from cooked foods., Cancer Res. 57 (1997) 195-197.

[18] M. Pollard, W. Wolter, Prevention of spontaneous prostate-related cancer in Lobund-Wistar rats by a soy protein isolate/isoflavone diet., Prostate. 45 (2000) 101-5. doi:10.1002/1097-0045(20001001)45:2<101::AID-PROS3>3.0.CO;2-P [pii].

[19] K.V.N. Rao, W.D. Johnson, M.C. Bosland, R.A. Lubet, V.E. Steele, G.J. Kelloff, D.L. Mccormick, Chemoprevention of Rat Prostate Carcinogenesis by Early and Delayed Administration of Dehydroepiandrosterone Chemoprevention of Rat Prostate Carcinogenesis by Early and Delayed Administration of Dehydroepiandrosterone 1, Cancer Res. (1999) 3084-3089.

[20] M. Onozawa, T. Kawamori, M. Baba, K. Fukuda, T. Toda, H. Sato, M. Ohtani, H. Akaza, T. Sugimura, K. Wakabayashi, Effects of a soybean isoflavone mixture on carcinogenesis in prostate and seminal vesicles of F344 rats., Japanese J. Cancer Res. 90 (1999) 393-98. doi:S0910505099800763 [pii].

[21] S. Banudevi, P. Elumalai, R. Arunkumar, K. Senthilkumar, D.N. Gunadharini, G. Sharmila, J. Arunakaran, Chemopreventive effects of zinc on prostate carcinogenesis induced by $\mathrm{N}$-methyl- $\mathrm{N}$-nitrosourea and testosterone in adult male Sprague-Dawley rats, J. Cancer Res. Clin. Oncol. 137 (2011) 677-686. doi:10.1007/s00432-010-0926-4.

[22] Senthilkumar, Arunkumar, Vijayababu, Kanagaraj, Aruldhas, Srinivasan, Arunakaran, Chemoprevention of $\mathrm{MNU}$ and Testosterone induced prostate carcinogenesis by Calcitriol ( vitamin D3) in adult male albino Wistar rats, Annu. Cancer Res. Ther. 14 (2006) 12-18.

[23] S. Takahashi, K. Takeshita, A. Seeni, S. Sugiura, M. Tang, S. Sato, H. Kuriyama, M. Nakadate, K. Abe, Y. Maeno, M. Nagao, T. Shirai, Suppression of prostate cancer 
in a transgenic rat model via gamma-tocopherol activation of caspase signaling., Prostate. 69 (2009) 644-651. doi:10.1002/pros.20915.

[24] D.L. McCormick, K.V.N. Rao, W.D. Johnson, M.C. Bosland, R.A. Lubet, V.E. Steele, Null Activity of Selenium and Vitamin E as Cancer Chemopreventive Agents in the Rat Prostate, Cancer Prev. Res. 3 (2010) 381-392. doi:10.1158/19406207.CAPR-09-0176.

[25] N.K. Narayanan, D. Nargi, L. Horton, B.S. Reddy, M.C. Bosland, B.A. Narayanan, Inflammatory processes of prostate tissue microenvironment drive rat prostate carcinogenesis: Preventive effects of celecoxib, Prostate. 69 (2009) 133-141. doi:10.1002/pros.20862.

[26] Y.-M. Cho, S. Takahashi, M. Asamoto, S. Suzuki, M. Tang, T. Shirai, Suppressive effects of antiandrogens, finasteride and flutamide on development of prostatic lesions in a transgenic rat model., Prostate Cancer Prostatic Dis. 10 (2007) 37883. doi:10.1038/sj.pcan.4500971.

[27] T. Shirai, S. Iwasaki, T. Masui, T. Mory, T. Kato, N. Ito, Enhancing effect of cadmiun or rat ventral prostate carcinogenesis induced by 3,2'-Dimethyl-4aminobiphenyl, Japanese J. Cancer Res. 84 (1993) 1023-1030.

[28] S. Suzuki, Y. Mori, A. Nagano, A. Naiki-Ito, H. Kato, Y. Nagayasu, M. Kobayashi, T. Kuno, S. Takahashi, Pioglitazone, a peroxisome proliferator-activated receptor $\gamma$ agonist, suppresses rat prostate carcinogenesis, Int. J. Mol. Sci. 17 (2016). doi:10.3390/ijms17122071.

[29] A. Naiki-Ito, T. Chewonarin, M. Tang, P. Pitchakarn, T. Kuno, K. Ogawa, M. Asamoto, T. Shirai, S. Takahashi, Ellagic acid, a component of pomegranate fruit juice, suppresses androgen-dependent prostate carcinogenesis via induction of apoptosis, Prostate. 75 (2015) 151-160. doi:10.1002/pros.22900.

[30] P. Sharma, S. McClees, F. Afaq, Pomegranate for Prevention and Treatment of Cancer: An Update, Molecules. 22 (2017) 177. doi:10.3390/molecules22010177.

[31] Y. Tagawa, K. Ozaki, S. Takahashi, K. Ogawa, T. Shirai, Lack of effects of postinitiation cholesterol on 3,2'-dimethyl-4- aminobiphenyl-induced prostate carcinogenesis, Prostate. 20 (1992) 179-185. doi:10.1002/pros.2990200303.

[32] T. Shirai, Significance of chemoprevention for prostate cancer development: Experimental in vivo approaches to chemoprevention, Pathol. Int. 58 (2008) 116. doi:10.1111/j.1440-1827.2007.02182.x.

[33] S.A. Shain, B. McCullough, A. Segaloff, Spontaneous adenocarcinomas of the ventral prostate of aged A X C rats, J. Natl. Cancer Inst. 55 (1975) 177-180.

[34] M. Pollard, Spontaneous prostate adenocarcinomas in aged germfree wistar rats, J. Natl. Cancer Inst. 51 (1973) 1235-1241. doi:10.1093/jnci/51.4.1235.

[35] T.R. Tennant, H. Kim, M. Sokoloff, C.W. Rinker-Schaeffer, The Dunning model, Prostate. 43 (2000) 295-302. doi:10.1002/1097-0045(20000601)43:4<295::AID- 
PROS9>3.0.CO;2-W.

[36] J.T. Isaacs, The Aging ACl/Seg versus Copenhagen Male Rat as a Model System for the Study of Prostatic Carcinogenesis, Cancer Res. 44 (1984) 5785-5796.

[37] M.S. Rao, V. Subbarao, D.G. Scarpelli, Effect of N-Nitrosobis (2-Oxopropyl) amine in newborn and suckling hamsters, Br. J. Cancer. 41 (1980) 996-999.

[38] T.A. Lawson, R. Gingell, D. Nagel, L.A. Hines, A. Ross, Methylation of hamster DNA by the carcinogen N-Nitroso-Bis (2-oxopropyl) amine, Cancer Lett. 11 (1981) 251-255.

[39] M.S. Rao, Development of billiary and hepatic neoplasms in guinea pigs treated with N-Nitrosobis(2-oxopropyl)amine, Cancer Lett. 5 (1978) 31-34.

[40] J.G. Farrelly, J.E. Saavedra, R.J. Kupper, M.L. Stewart, The metabolism of Nnitrosobis(2-oxopropyl)amine by microsomes and hepatocytes from Fischer 344 rats, Carcinogenesis. 8 (1987) 1095-1099.

[41] P.M. Pour, K. Groot, K. Kazakoff, K. Anderson, A. V. Schally, Effects of High-Fat Diet on the Patterns of Prostatic Cancer Induced in Rats by N-Nitrosobis(2oxopropyl)amine and Testosterone, Cancer Res. 51 (1991) 4757-4761.

[42] A.I. Faustino-Rocha, R. Ferreira, P.A. Oliveira, A. Gama, M. Ginja, N-Methyl-Nnitrosourea as a mammary carcinogenic agent, Tumor Biol. 36 (2015) 90959117. doi:10.1007/s13277-015-3973-2.

[43] Institute Molecular Screening Center, National Center for Biotechnology Information. PubChem Substance Database; $C I D=12699$, Source=Scripps Research, (n.d.).

[44] M.C. Bosland, M.K. Prinsen, R. Kroes, Adenocarcinomas of the prostate induced by $\mathrm{N}$-Nitroso-N-Methylurea in rats preteated with cyproterone acetate and testosterone, Cancer Lett. 18 (1983) 69-78.

[45] M. Pollard, P.H. Luckert, Promotional effects of testosterone and high fat diet on the development of autochthonous prostate cancer in rats, Cancer Lett. 32 (1986) 223-227. doi:10.1016/0304-3835(86)90123-0.

[46] M.C. Bosland, Testosterone treatment is a potent tumor promoter for the rat prostate, Endocrinology. 155 (2014) 4629-4633. doi:10.1210/en.2014-1688.

[47] M.C. Bosland, Is there a future for chemoprevention of prostate cancer?, Cancer Prev. Res. 9 (2016) 642-647. doi:10.1158/1940-6207.CAPR-16-0088.

[48] W.P. Steward, K. Brown, Cancer chemopreventive: a rapidly evolving field, Br. J. Cancer. 109 (2013) 1-7.

[49] T. Shirai, M. Tada, M. Kojima, R. Hasegawa, T. Masui, N. Ito, DNA Adducts in Target and Nontarget Tissues of 3,2' -Dimethyl-4-Aminobiphenyl in Rats, Environ. Health Perspect. 102 (1994) 167-172. doi:10.2307/3432172. 
[50] S. Katayana, E. Fiala, B.S. Reddy, A. Rivenson, J. Silverman, G. Williams, J.H. Weisburger, Prostate adenocarcinoma in rats: induction by 3,2'-dimethyl-4aminobiphenyl, J. Natl. Cancer Inst. 68 (1982) 867-873.

[51] N. Ito, T. Shirai, Y. Tagawa, A. Nakamura, S. Fukushima, Variation in Tumor Yield in the Prostate and other Target Organs of the Rat in Response to Varied Dosage and Duration of Administration, Cancer Res. 48 (1988) 4629-4632.

[52] T. Shirai, S. Tamano, M. Sano, K. Imaida, A. Hagiwara, M. Futakuchi, S. Takahashi, M. Hirose, Site-specific Effects of Testosterone Propionate on the Prostate of Rat Pretreated with 3,2'-Dimethyl-4-aminobiphenyl: Dosedependent Induction of Invasive Carcinomas, Japanese J. Cancer Res. 86 (1995) 645-648.

[53] T. Shirai, A. Nakamura, S. Fukushima, A. Yamamoto, M. Tada, N. Ito, Different carcinogenic responses in a variety of organs, including the prostate, of five different rat strains given 3,2'-dimethyl-4-aminobiphenyl, Carcinogenesis. 11 (1990) 793-797. doi:10.1093/carcin/11.5.793.

[54] T. Shirai, S. Tamano, T. Kato, S. Iwasaki, S. Takahashi, N. Ito, Induction of Invasive Carcinomas in the Accessory Sex Organs Other Than the Ventral Prostate of Rats Given 3,2'-Dimethyl-4-aminobiphenyl and Testosterone Propionate, Cancer Res. 51 (1991) 1264-1269.

[55] H. Kohno, Y. Tsukio, Y. Yanaida, M. Tanino, T. Tanaka, Lack of modifying effects of 4-n-octylphenol on 3,2'-dimethyl-4-aminobiphenyl-induced prostate carcinogenesis in rats., Ecotoxicol. Environ. Saf. 51 (2002) 210-5. doi:10.1006/eesa.2002.2132.

[56] M.X. Tang, K. Ogawa, M. Asamoto, T. Chewonarin, S. Suzuki, T. Tanaka, T. Shirai, Effects of Nobiletin on PhIP-Induced Prostate and Colon Carcinogenesis in F344 Rats, Nutr. Cancer. 63 (2011) 227-233. doi:10.1080/01635581.2011.523506.

[57] E.G. Snyderwine, M. Venugopal, M. Yu, Mammary gland carcinogenesis by foodderived heterocyclic amines and studies on the mechanisms of carcinogenesis of 2-amino-1-methyl-6-phenylimidazo[4,5-b]pyridine (PhIP), Mutat. Res. - Fundam. Mol. Mech. Mutagen. 506-507 (2002) 145-152. doi:10.1016/S00275107(02)00161-6.

[58] K. Takayama, K. Yamashita, K. Wakabayashi, T. Sugimura, M. Nagao, DNA modification by 2-Amino-1-methyl-6-phenylimidazo[4,5-b]pyridine in rats, Japanese J. Cancer Res. 80 (1989) 1145-1148.

[59] K. Canene-Adams, K.S. Sfanos, C.T. Liang, S. Yegnasubramanian, W.G. Nelson, C. Brayton, A.M. De Marzo, Dietary chemoprevention of PhIP induced carcinogenesis in male Fischer 344 rats with tomato and broccoli, PLoS One. 8 (2013). doi:10.1371/journal.pone.0079842.

[60] T. Shirai, L. Cui, S. Takahashi, M. Futakuchi, M. Asamoto, K. Kato, N. Ito, Carcinogenicity of 2-amino-1-methyl-6-phenylimidazo[4,5-b]pyridine (PhIP) in 
the rat prostate and induction of invasive carcinomas by subsequent treatment with testosterone propionate, Cancer Lett. 143 (1999) 217-221. doi:10.1016/S0304-3835(99)00128-7.

[61] A. Hikosaka, M. Asamoto, N. Hokaiwado, K. Kato, K. Kuzutani, K. Kohri, T. Shirai, Inhibitory effects of soy isoflavones on rat prostate carcinogenesis induced by 2 amino-1-methyl-6-phenylimidazo[4,5-b]pyridine (PhIP), Carcinogenesis. 25 (2004) 381-387. doi:10.1093/carcin/bgh031.

[62] K. Imaida, S. Tamano, K. Kato, Y. Ikeda, M. Asamoto, S. Takahashi, Z. Nir, M. Murakoshi, H. Nishino, T. Shirai, Lack of chemopreventive effects of lycopene and curcumin on experimental rat prostate carcinogenesis., Carcinogenesis. 22 (2001) 467-72. doi:10.1093/carcin/22.3.467.

[63] N. Özten, L. Horton, S. Lasano, M.C. Bosland, Selenomethionine and $\alpha$ tocopherol do not inhibit prostate carcinogenesis in the testosterone plus estradiol-treated NBL rat model, Cancer Prev. Res. 3 (2010) 371-380. doi:10.1158/1940-6207.CAPR-09-0152.

[64] G. Leung, I.F.F. Benzie, A. Cheung, S.W. Tsao, Y.C. Wong, No effect of a high-fat diet on promotion of sex hormone-induced prostate and mammary carcinogenesis in the Noble rat model., Br. J. Nutr. 88 (2002) 399-409. doi:10.1079/BJN2002673.

[65] A. Hsu, R.S. Bruno, C. V. Löhr, A.W. Taylor, R.H. Dashwood, T.M. Bray, E. Ho, Dietary soy and tea mitigate chronic inflammation and prostate cancer via NFKB pathway in the Noble rat model, J. Nutr. Biochem. 22 (2011) 502-510. doi:10.1016/j.jnutbio.2010.04.006.

[66] V. Tumati, S. Mathur, K. Song, J.-T. Hsieh, D. Zhao, M. Takahashi, T. Dobin, L. Gandee, T.D. Solberg, A. a Habib, D. Saha, Development of a locally advanced orthotopic prostate tumor model in rats for assessment of combined modality therapy., Int. J. Oncol. 42 (2013) 1613-9. doi:10.3892/ijo.2013.1858.

[67] N. Kawai, A. Ito, Y. Nakahara, M. Futakuchi, T. Shirai, H. Honda, T. Kobayashi, K. Kohri, Anticancer effect of hyperthermia on prostate cancer mediated by magnetite cationic liposomes and immune-response induction in transplanted syngeneic rats, Prostate. 64 (2005) 373-381. doi:10.1002/pros.20253.

[68] H.B. Pollard, M.A. Levine, O. Eidelman, M. Pollard, Pharmacological ascorbic acid suppresses syngeneic tumor growth and metastases in hormone-refractory prostate cancer, In Vivo (Brooklyn). 24 (2010) 249-255. doi:24/3/249 [pii].

[69] H. Nakanishi, S. Takeuchi, K. Kato, S. Shimizu, K. Kobayashi, M. Tatematsu, T. Shirai, Establishment and Characterization of Three Androgen-independent, Metastic Carcinoma Cell Lines from 3,2'-Dimethyl-4-aminobiphenyl-induced Prostatic Tumors in F344 Rats, Japanese J. Cancer Res. 87 (1996) 1218-1226.

[70] J.M. Bentel, M. a Pickering, M. Pollard, J. a Clements, W.D. Tilley, Androgen receptor expression in primary prostate cancers of Lobund-Wistar rats and in 
tumor-derived cell lines., In Vitro Cell. Dev. Biol. Anim. 35 (1999) 655-62. doi:10.1007/s11626-999-0106-5.

[71] B.L. Neubauer, K.G. Bemis, K.L. Best, R.L. Goode, R.L. Merriman, G.F. Smith, L.R. Tanzer, D.M. Hoover, Metastatic Spread of the PAHI Prostatic Adenocarcinoma After Implantation in the Tail of the Rat, Prostate. 8 (1986) 265-276.

[72] D.J. McCullough, L.M.-D. Nguyen, D.W. Siemann, B.J. Behnke, Effects of exercise training on tumor hypoxia and vascular function in the rodent preclinical orthotopic prostate cancer model, J. Appl. Physiol. 115 (2013) 1846-1854. doi:10.1152/japplphysiol.00949.2013.

[73] D.J. McCullough, J.N. Stabley, D.W. Siemann, B.J. Behnke, Modulation of blood flow, hypoxia, and vascular function in orthotopic prostate tumors during exercise, J. Natl. Cancer Inst. 106 (2014). doi:10.1093/jnci/dju036.

[74] M. Johannsen, B. Thiesen, A. Jordan, K. Taymoorian, U. Gneveckow, N. Waldöfner, R. Scholz, M. Koch, M. Lein, K. Jung, S.A. Loening, Magnetic fluid hyperthermia (MFH) reduces prostate cancer growth in the orthotopic Dunning R3327 rat model, Prostate. 64 (2005) 283-292. doi:10.1002/pros.20213.

[75] J.K. Simmons, S.M. Elshafae, E.T. Keller, L.K. Mccauley, T.J. Rosol, Review of Animal Models of Prostate Cancer Bone Metastasis, Vet. Sci. 1 (2014) 16-39. doi:10.3390/vetsci1010016.

[76] C. Andresen, C.M. Bagi, S.W. Adams, Intra-tibial injection of human prostate cancer cell line CWR22 elicits osteoblastic response in immunodeficient rats, J. Musculoskelet. Neuronal Interact. 3 (2003) 148-155.

[77] C.E. Harper, B.B. Patel, L.M. Cook, J. Wang, T. Shirai, I. a Eltoum, C. a Lamartiniere, Characterization of SV-40 Tag rats as a model to study prostate cancer., BMC Cancer. 9 (2009) 30. doi:10.1186/1471-2407-9-30.

[78] M. Asamoto, N. Hokaiwado, Y.M. Cho, S. Takahashi, Y. Ikeda, K. Imaida, T. Shirai, Prostate carcinomas developing in transgenic rats with SV40 T antigen expression under probasin promoter control are strictly androgen dependent, Cancer Res. 61 (2001) 4693-4700.

[79] L. Johnson, J. Becker, J. Dubovsky, B. Olson, D. McNeel, Prostate carcinoma in trangenic Lewis rats - a tumor model for evaluation of immunological treatments, Chinese Clin. Oncol. (2013). doi:10.1016/j.humov.2008.02.015.Changes.

[80] S. Sarkar, S. Das, A Review of Imaging Methods for Prostate Cancer Detection, 7 (2016) 1-15. doi:10.4137/BECB.S34255.TYPE.

[81] J. Eastham, Prostate cancer screening, Investig Clin Urol. 58 (2017) 217-219.

[82] E.J. Trabulsi, W.G. Merriam, L.G. Gomella, New imaging techniques in prostate cancer, Curr. Urol. Rep. 7 (2006) 175-180. 
[83] M. Rudin, S. Qureshi, L. Tolcsvai, R.A. Siegel, Visualization and quantification of transplanted Dunning prostate tumors in rats using magnetic resonance imaging, Prostate. 12 (1988) 333-341.

[84] H. Cho, E. Ackerstaff, S. Carlin, M.E. Lupu, Y. Wang, A. Rizwan, J. O’Donoghue, C.C. Ling, J.L. Humm, P.B. Zanzonico, J.A. Koutcher, Noninvasive multimodality imaging of the tumor microenvironment: registered dynamic magnetic resonance imaging and positron emission tomography studies of a preclinical tumor model of tumor hypoxia., Neoplasia. 11 (2009) 247-59. doi:10.1593/neo.81360.

[85] S. Verma, A. Rajesh, A clinically relevant approach to imaging prostate cancer: Review, Am. J. Roentgenol. 196 (2011) 1-10. doi:10.2214/AJR.09.7196.

[86] H. Aydin, V. Kizilgoz, I. Tatar, C. Damr, A. Ugan, I. Paker, B. Hekimoglu, Detection of Prostate Cancer With Magnetic Resonance Sequences and MR Spectroscopy, Correlated With Biopsy and Histopathological Findings, J Comput Assist Tomogr. 36 (2012) 30-45.

[87] J.J. Fox, H. Schoder, S.M. Larson, Molecular imaging of prostate cancer., Curr Opin Urol. 22 (2012) 320-327. doi:10.1097/MOU.0b013e32835483d5.

[88] C.C. Cyran, J.C. von Einem, P.M. Paprottka, B. Schwarz, M. Ingrisch, O. Dietrich, R. Hinkel, C.J. Bruns, D.A. Clevert, R. Eschbach, M.F. Reiser, B.J. Wintersperger, K. Nikolaou, Dynamic Contrast-Enhanced Computed Tomography Imaging Biomarkers Correlated With Immunohistochemistry for Monitoring the Effects of Sorafenib on Experimental Prostate Carcinomas, Invest. Radiol. 47 (2012) 4957. doi:10.1097/RLI.0b013e3182300fe4.

[89] D.L. Mccormick, K.V.N. Rao, V.E. Steele, D.L. Mccormick, K.V.N. Rao, V.E. Steele, R.A. Lubet, G.J. Kelloff, M.C. Bosland, Chemoprevention of Rat Prostate Carcinogenesis by 9- cis -Retinoic Acid Advances in Brief Chemoprevention of Rat Prostate Carcinogenesis by 9- cis -Retinoic Acid 1, (1999) 521-524.

[90] S. Inaguma, S. Takahashi, K. Imaida, S. Suzuki, T. Shirai, P-Nonylphenol pretreatment during the late neonatal period has no effect on 3,2'-dimethyl-4aminobiphenyl-induced prostate carcinogenesis in male F344 rats, Cancer Lett. 212 (2004) 159-166. doi:10.1016/j.canlet.2004.03.028.

[91] M.S. LUCIA, M.A. ANZANO, M. V SLAYTER, M.R. ANVER, D.M. GREEN, M.W. SHRADER, D.L. LOGSDON, C.L. DRIVER, C.C. BROWN, C.W. PEER, A.B. ROBERTS, M.B. SPORN, Chemopreventive Activity of Tamoxifen, N-(4Hydroxyphenl)Retinamide, and the Vitamin-D Analog Ro24-5531 for AndrogenPromoted Carcinomas of the Rat Seminal-Vesicle and Prostate, Cancer Res. 55 (1995) 5621-5627.

[92] F. B., V. R.J., An animal model for the study of prostatic adenocarcinomas, Investig Clin Urol. 15 (1977) 42-48.

[93] P.M. Pour, Prostatic cancer induced in MRC rats by $\mathrm{N}^{\prime}$-nitrosobis(2- 
oxopropyl)amine and N-nitrosobis(2-hydroxypropyl)-amine, Carcinogenesis. 4 (1983) 49-55.

[94] J.M. Ward, G. Reznik, S.F. Stinson, C.P. Lattirada, D.G. Longfellow, T.P. Cameron, Histogenesis and morphology of naturally occurring prostatic carcinoma in the ACl/segHapBR rat, Lab. Invest. 43 (1980) 517-522.

[95] M.C. Bosland, M.K. Prinsen, Induction of Dorsolateral Prostate Adenocarcinomas and Other Accessory Sex Gland Lesions in Male Wistar Rats by a Single Administration of N-Methyl- N-nitrosourea , 7, 12-Dimethylbenz ( a Sequential Treatment with Cyproterone Acetate and Testosterone P, Cancer Res. 50 (1990) 691-699.

[96] M.C. Bosland, Lesions in the male accessory sex glands and penis, in: U. Mohr, D.L. Dungworth, C.C. Capen (Eds.), Pathol. Aging Rat, ILSI Press, Washington DC, 1992: pp. 443-467.

[97] N. Ito, T. Shirai, Tumours of the accessory male sex organs, in: U. Mohr (Ed.), Pathol. Tumours Lab. Anim., IARC Scientiéc Publication, Lyon, 1990: pp. 421443.

[98] T. SHIRAI, S. FUKUSHIMA, E. IKAWA, Y. TAGAWA, N. ITO, Induction of Prostate Carcinoma in situ at High-Incidence in F344 Rats By a Combination of 3,2'Dimethyl-4 Aminobiphenyl and Ethinyl Estradiol, Cancer Res. 46 (1986) 64236426.

[99] M. Pollard, P.H. Luckert, Production of autochthonous prostate cancer in Lobund-Wistar rats by treatments with $A^{\prime}$-methyl-/V-nitrosourea and testosterone, J Nati. Cancer Inst. 32 (1986) 583-587.

[100] M.C. Bosland, D.L. Tuomari, M.R. Elwell, T. Shirai, J.M. Ward, M. R.F., Proliferative lesions of the prostate and other accessory sex glands in male rats, in: Guid. Toxicol. Pathol., STP/ARP/AF, Washington DC, 1998: pp. 1-20.

[101] T. Suwa, N. A, P. JC, H. JR, M. JF, H. JK, M. RR, A retrospective analysis of background lesions and tissue accountability for male accessory sex organs in Fischer-344 rats, Toxicol Pathol. 29 (2001) 467-478.

[102] D.L. Mccormick, K.V.N. Rao, L. Dooley, V.E. Steele, R.A. Lubet, G.J. Kelloff, M.C. Bosland, Influence of N-Methyl-N-Nitrosourea, Testosterone, and N-(4Hydroxyphenyl)-all- trans-retinamide on Prostate Cancer Induction in WistarUnilever Rats, (1998) 3282-3288.

[103] J.-F. Bisson, M.-A. Guardia-Llorens, S. Hidalgo, P. Rozan, M. Messaoudi, Protective effect of Acticoa powder, a cocoa polyphenolic extract, on prostate carcinogenesis in Wistar-Unilever rats, Eur. J. Cancer Prev. 17 (2008) 54-61. doi:10.1097/CEJ.0b013e3280145b33.

[104] B.A. Narayanan, B.S. Reddy, M.C. Bosland, D. Nargi, L. Horton, C. Randolph, N.K. Narayanan, Exisulind in combination with celecoxib modulates epidermal growth factor receptor, cyclooxygenase-2, and cyclin D1 against prostate 
carcinogenesis: In vivo evidence, Clin. Cancer Res. 13 (2007) 5965-5973. doi:10.1158/1078-0432.CCR-07-0744.

[105] D.L. McCormick, W.D. Johnson, T.M. Haryu, M.C. Bosland, R.A. Lubet, V.E. Steele, Null Effect of Dietary Restriction on Prostate Carcinogenesis in the Wistar-Unilever Rat, Nutr. Cancer. $57 \quad$ (2007) 194-200. doi:10.1080/01635580701277494.

[106] D.L. McCormick, W.D. Johnson, M.C. Bosland, R.A. Lubet, V.E. Steele, Chemoprevention of Rat Prostate Carcinogenesis by Soy Isoflavones and by Bowman-Birk Inhibitor, Nutr. Cancer. 57 (2007) 184-193. doi:10.1080/01635580701277478.

[107] L.D. Sanches, S.A.A. Santos, J.R. Carvalho, G.D.M. Jeronimo, W.J. Favaro, M.D.G. Reis, S.L. Felisbino, L.A. Justulin, Protective effect of $\gamma$-tocopherol-enriched diet on N-methyl-N-nitrosourea-induced epithelial dysplasia in rat ventral prostate, Int. J. Exp. Pathol. 94 (2013) 362-372. doi:10.1111/iep.12042.

[108] T.W.-M. Boileau, Z. Liao, S. Kim, S. Lemeshow, J.W. Erdaman, S.K. Clinton, Prostate Carcinogenesis in N-methyl-N-nitrosourea (NMU)-TestosteroneTreated Rats Fed Tomato Powder, Lycopene, or Energy-Restricted Diets, J. Natl. Cancer Inst. 95 (2003) 1578-1586. doi:10.1093/jnci/djg081.

[109] A. Arunkumar, M.R. Vijayababu, P. Venkataraman, K. Senthilkumar, J. Arunakaran, Chemoprevention of rat prostate carcinogenesis by diallyl disulfide, an organosulfur compound of garlic., Biol. Pharm. Bull. 29 (2006) 375-379. doi:10.1248/bpb.29.375.

[110] D.L. McCormick, W.D. Johnson, N.M. Kozub, K.V.N. Rao, R.A. Lubet, V.E. Steele, M.C. Bosland, Chemoprevention of rat prostate carcinogenesis by dietary $16 \alpha-$ fluoro-5-androsten-17-one (fluasterone), a minimally androgenic analog of dehydroepiandrosterone, Carcinogenesis. $28 \quad$ (2007) 398-403. doi:10.1093/carcin/bgl141.

[111] H. Chiu, M. Chen, W. Fang, C. Hung, Y. Chen, M. Wu, G. Yuan, M. Wu, Y. Wang, Preventive Effects of Monascus on Androgen-Related Diseases: Androgenetic Alopecia, Benign Prostatic Hyperplasia, and Prostate Cancer, J. Agric. Food Chem. 61 (2013) 4379-4386.

[112] J. Wang, I.E. Eltoum, M. Carpenter, C. a. Lamartiniere, Genistein mechanisms and timing of prostate cancer chemoprevention in Lobund-Wistar rats, Asian Pacific J. Cancer Prev. 10 (2009) 143-150.

[113] J. Wang, I.E. Eltoum, C.A. Lamartiniere, Dietary genistein suppresses chemically induced prostate cancer in Lobund-Wistar rats, Cancer Lett. 186 (2002) 11-18. doi:10.1016/S0304-3835(01)00811-4.

[114] M.A. Suckow, W.R. Wolter, V.T. Sailes, Inhibition of prostate cancer metastasis by administration of a tissue vaccine, Clin. Exp. Metastasis. 25 (2008) 913-918. doi:10.1007/s10585-008-9213-z. 
[115] I.B.J.K. Joseph, J. Vukanovic, J.T. Isaacs, Antiangiogenic treatment with linomide as chemoprevention for prostate, seminal vesicle, and breast carcinogenesis in rodents, Cancer Res. 56 (1996) 3404-3408.

[116] M. Pollard, Effects of linomide on advanced prostate-seminal vesicle cancers in Lobund- Wistar rats, Prostate. 35 (1998) 43-49. doi:10.1002/(SICI)10970045(19980401)35:1<43::AID-PROS6>3.0.CO;2-I.

[117] M. Pollard, P.H. Luckert, M.B. Sporn, Prevention of primary prostate cancer in Lobund-Wistar rats by N- (4-hydroxyphenyl)retinamide, Cancer Res. 51 (1991) 3610-3611.

[118] A. Yamauchi, K. Kawai, S. Tsukamoto, Y. Ideyama, T. Shirai, H. Akaza, Persistence of prostatic intraepithelial neoplasia after effective chemoprevention of microscopic prostate cancer with antiandrogen in a rat model, J. Urol. 175 (2006) 348-352. doi:10.1016/S0022-5347(05)00002-9.

[119] T. Mori, K. Imaida, S. Tamano, M. Sano, S. Takahashi, M. Asamoto, M. Takeshita, H. Ueda, T. Shirai, Beef tallow, but not perilla or corn oil, promotion of rat prostate and intestinal carcinogenesis by 3,2'-dimethyl-4-aminobiphenyl., Jpn. J. Cancer Res. 92 (2001) 1026-1033. doi:10.1111/j.1349-7006.2001.tb01056.x.

[120] S. Tsukamoto, H. Akaza, M. Onozawa, T. Shirai, Y. Ideyama, A five-alpha reductase inhibitor or an antiandrogen prevents the progression of microscopic prostate carcinoma to macroscopic carcinoma in rats, Cancer. 82 (1998) 531537. doi:10.1002/(SICI)1097-0142(19980201)82:3<531::AID-CNCR15>3.0.CO;22.

[121] K. Kato, S. Takahashi, L. Cui, T. Toda, S. Suzuki, M. Futakuchi, S. Sugiura, T. Shirai, Suppressive effects of dietary genistin and daidzin on rat prostate carcinogenesis., Japanese J. Cancer Res. 91 (2000) 786-91.

[122] M. Kawabe, M.-A. Shhibata, M. Sano, Y. Takesada, S. Tamano, N. Ito, T. Shirai, Decrease of Prostaglandin E2 and 5-Bromo-2'-dexyridine Labeling but Not Prostate Tumor Development by Indomethacin Treatment of Rats Given 3,2'Dimethyl-4-aminobiphenyl and Testosterone Propionate, Japanese J. Cancer Res. 88 (1997) 350-355.

[123] H. Kohno, R. Suzuki, S. Sugie, H. Tsuda, T. Tanaka, Lack of modifying effects of 4tert-octylphenol and benzyl butyl phthalate on 3,2'-dimethyl-4-aminobiphenylinduced prostate crcinogenesis in rats, Cancer Sci. 95 (2004) 300-305.

[124] H. Kohno, R. Suzuki, S. Sugie, H. Tsuda, T. Tanaka, Dietary supplementation with silymarin inhibits 3,2'-dimethyl-4-aminobiphenyl-induced prostate carcinogenesis in male F344 rats, Clin Cancer Res. 11 (2005) 4962-4967. doi:10.1158/1078-0432.ccr-05-0137.

[125] L. Cui, T. Mori, S. Takahashi, K. Imaida, K. Akagi, H. Yada, M. Yaono, T. Shirai, Slight promotion effects of intermittent administration of testosterone propionate and/or diethylstilbestrol on 3,2'-dimethyl-4-aminobiphenyl-initiated 
rat prostate carcinogenesis, Cancer Lett. 122 (1998) 195-199. doi:10.1016/S0304-3835(97)00390-X.

[126] J. Gueritat, L. Lefeuvre-Orfila, S. Vincent, A. Cretual, J.L. Ravanat, A. GratasDelamarche, F. Rannou-Bekono, A. Rebillard, Exercise training combined with antioxidant supplementation prevents the antiproliferative activity of their single treatment in prostate cancer through inhibition of redox adaptation, Free Radic. Biol. Med. 77 (2014) 95-105. doi:10.1016/j.freeradbiomed.2014.09.009.

[127] L.A. Cohen, Z. Zhao, B. Pittman, J. Scimeca, Effect of soy protein isolate and conjugated linoleic acid on the growth of dunning R-3327-AT-1 rat prostate tumors, Prostate. 54 (2003) 169-180. doi:10.1002/pros.10127.

[128] B.L. Lindshield, N.A. Ford, K. Canene-Adams, A.M. Diamond, M.A. Wallig, J.W. Erdman, Selenium, but not lycopene or vitamin E, decreases growth of transplantable dunning R3327-H rat prostate tumors, PLoS One. 5 (2010) 1-9. doi:10.1371/journal.pone.0010423.

[129] R.D. Tucker, S.A. Loening, S. Landas, A.H. Mardan, Z.Y. Ren, D.M. Lubaroff, The in vivo effect of regional hyperthermia on dunning R3327 prostatic tumor., Prostate. 18 (1991) 321-329.

[130] T. Zaccheo, D. Giudici, E. Salle, Combined treatment with the $5 \alpha$-reductase inhibitor PNU 157706 and the antiandrogen flutamide on the Dunning R3327 prostatic carcinoma in rats, Endocr. Relat. Cancer. 6 (1999) 429-435.

[131] J. Smith, P. Ghayad, C.B. Dhabuwala, A. Drelichman, J. Pierce, The effects of Cyclophosphamide, Ketoconazole, Aclacinomycin-A, Methotrexate, and Scheduled Methotrexate-5-Fluorouracil Combination Chemotherapy on the Transplantable R-3327 Prostatic Adenocarcinoma in the F1 Hybrid Male Rat, Cancer. 56 (1985) 1045-1048.

[132] A. Widmark, J.E. Damber, A. Bergh, R. Henriksson, Estramustine potentiates the effects of irradiation on the Dunning (R3327) rat prostatic adenocarcinoma, Prostate. 24 (1994) 79-83.

[133] J. Damber, A. Bergh, L. Daehlin, V. Petrow, M. Landstram, Effects of 6-Methylene Progesterone on Growth, Morphology, and Blood Flow of the Dunning R3327 Prostatic Adenocarcinoma, 197 (1992) 187-197.

[134] P. Colin, P. Nevoux, M. Marqa, F. Auger, X. Leroy, A. Villers, P. Puech, S. Mordon, N. Betrouni, Focal laser interstitial thermotherapy (LITT) at $980 \mathrm{~nm}$ for prostate cancer: Treatment feasibility in Dunning R3327-AT2 rat prostate tumour, BJU Int. 109 (2012) 452-458. doi:10.1111/j.1464-410X.2011.10406.x.

[135] P. Paparel, L. Curiel, S. Chesnais, R. Ecochard, J.Y. Chapelon, A. Gelet, Synergistic inhibitory effect of high-intensity focused ultrasound combined with chemotherapy on Dunning adenocarcinoma, BJU Int. 95 (2005) 881-885. doi:10.1111/j.1464-410X.2005.05420.x.

[136] J.P. Gaddipati, N. V Rajeshkumar, R.L. Thangapazham, A. Sharma, J. Warren, S.R. 
Mog, A.K. Singh, R.K. Maheshwari, Protective effect of a polyherbal preparation, Brahma rasayana against tumor growth and lung metastasis in rat prostate model system., J. Exp. Ther. Oncol. 4 (2004) 203-212.

[137] B.L. Lokeshwar, G.G. Schwartz, M.G. Selzer, K.L. Burnstein, S.H. Zhuang, N.L. Block, L. Binderup, Inhibition of prostate cancer metastasis in vivo: a comparison of 1,23-dihydroxyvitamin D (calcitriol) and EB1089, Cancer Epidemiol. Biomarkers Prev. 8 (1999) 241-8.

[138] B.L. Lokeshwar, M.G. Selzer, B.Q. Zhu, N.L. Block, L.M. Golub, Inhibition of cell proliferation, invasion, tumor growth and metastasis by an oral nonantimicrobial tetracycline analog (COL-3) in a metastatic prostate cancer model, Int. J. Cancer. 98 (2002) 297-309. doi:10.1002/ijc.10168.

[139] R.H. Getzenberg, B.W. Light, P.E. Lapco, B.R. Konety, A.K. Nangia, J.S. Acierno, R. Dhir, Z. Shurin, R.S. Day, D.L. Trump, C.S. Johnson, Vitamin D inhibition of prostate adenocarcinoma growth and metastasis in the dunning rat prostate model system, Urology. 50 (1997) 999-1006. doi:10.1016/S00904295(97)00408-1.

[140] G.M. Oades, K. Dredge, R.S. Kirby, K.W. Colston, Vitamin D receptor-dependent antitumour effects of 1,25 -dihydroxyvitamin $D 3$ and two synthetic analogues in three in vivo models of prostate cancer, BJU Int. 90 (2002) 607-616. doi:10.1046/j.1464-4096.2002.02964.x.

[141] I. Bugan, Z. Karagoz, S. Altun, M.B.A. Djamgoz, Gabapentin, an Analgesic Used Against Cancer-Associated Neuropathic Pain: Effects on Prostate Cancer Progression in an In Vivo Rat Model, Basic Clin. Pharmacol. Toxicol. 118 (2016) 200-207. doi:10.1111/bcpt.12484.

[142] H. Naik, J. Lehr, K.J. Pienta, Inhibition of prostate cancer growth by 9aminocampthothecin and estramustine, Urology. 48 (1996) 508-511. doi:10.1002/pros.2990260606.

[143] M. Fakih, T. Replogle, J.E. Lehr, K.J. Pienta, A. Yagoda, Inhibition of prostate cancer growth by estramustine and colchicine, Prostate. 26 (1995) 310-315. doi:10.1002/pros.2990260606.

[144] K.J. Pienta, H. Naik, J.E. Lehr, Effect of estramustine, etoposide, and taxol on prostate cancer cell growth in vitro and in vivo, Urology. 48 (1996) 164-170.

[145] S.A. Rabbani, P. Harakidas, T. Bowlin, G. Attardo, Effect of nucleoside analogue $\mathrm{BCH}-4556$ on prostate cancer growth and metastases in vitro and in vivo, Cancer Res. 58 (1998) 3461-3465.

[146] S. Shikanov, A. Shikanov, G. O, A. Nyska, B. Corn, A. Domb, Intratumoral Delivery of Paclitaxel for Treatment of Orthotopic Prostate Cancer, J. Pharm. Sci. 98 (2009) 1005-2014. doi:10.1002/jps.

[147] K.J. Pienta, T. Replogle, J.E. Lehr, Inhibition of prostate cancer growth by Vinlastine and Tamoxifen, Prostate. 26 (1995) 270-273. 
doi:10.1002/pros.2990260606.

[148] M. Johannsen, B. Thiesen, U. Gneveckow, K. Taymoorian, N. Waldöfner, R. Scholz, S. Deger, K. Jung, S.A. Loening, A. Jordan, Thermotherapy using magnetic nanoparticles combined with external radiation in an orthotopic rat model of prostate cancer, Prostate. 66 (2006) 97-104. doi:10.1002/pros.20324.

[149] S. Suzuki, K. Shiraga, S. Sato, W. Punfa, A. Naiki-lto, Y. Yamashita, T. Shirai, S. Takahashi, Apocynin, an NADPH oxidase inhibitor, suppresses rat prostate carcinogenesis, Cancer Sci. 104 (2013) 1711-1717. doi:10.1111/cas.12292.

[150] Y. Zeng, M. Yokohira, H. Takeuchi, K. Saoo, K. Yamakawa, Y. Matsuda, K. Hosokawa, J.Q. Li, M. Ikeda, K. Imaida, Lack of significant modifying effect of arctiin on prostate carcinogenesis in probasin/SV40 T antigen transgenic rats, Cancer Lett. 222 (2005) 145-151. doi:10.1016/j.canlet.2004.09.026.

[151] H. Kandori, S. Suzuki, M. Asamoto, T. Murasaki, T. Mingxi, K. Ogawa, T. Shirai, Influence of atrazine administration and reduction of calorie intake on prostate carcinogenesis in probasin/SV40 T antigen transgenic rats, Cancer Sci. 96 (2005) 221-226. doi:10.1111/j.1349-7006.2005.00041.x.

[152] C.E. Harper, L.M. Cook, B.B. Patel, J. Wang, I.A.- Eltoum, A. Arabshari, T. Shirai, C.A. Lamartiniere, Genistein and Resveratrol, Alone and in Combination, Suppress Prostate Cancer in SV-40 TAg Rats, Prostate. 69 (2009) 1668-1682. doi:10.1038/jid.2014.371.

[153] M.M. Said, N. Hokaiwado, M. Tang, K. Ogawa, S. Suzuki, H.M. Ghanem, A.Y. Esmat, M. Asamoto, F.M. Refaie, T. Shirai, Inhibition of prostate carcinogenesis in probasin/SV40 T antigen transgenic rats by leuprorelin, a luteinizing hormonereleasing hormone agonist, Cancer Sci. 97 (2006) 459-467. doi:10.1111/j.13497006.2006.00213.x.

[154] M.X. Tang, K. Ogawa, M. Asamoto, N. Hokaiwado, A. Seeni, S. Suzuki, S. Takahashi, T. Tanaka, K. Ichikawa, T. Shirai, Protective effects of citrus nobiletin and auraptene in transgenic rats developing adenocarcinoma of the prostate (TRAP) and human prostate carcinoma cells, Cancer Sci. 98 (2007) 471-477. doi:10.1111/j.1349-7006.2007.00417.x.

[155] Y. Zeng, M. Yokohira, K. Saoo, H. Takeuchi, Y. Chen, K. Yamakawa, Y. Matsuda, Y. Kakehi, K. Imaida, Inhibition of prostate carcinogenesis in probasin/SV40 T antigen transgenic rats by raloxifene, an antiestrogen with anti-androgen action, but not nimesulide, a selective cyclooxygenase-2 inhibitor, Carcinogenesis. 26 (2005) 1109-1116. doi:10.1093/carcin/bgi056.

[156] A. Seeni, S. Takahashi, K. Takeshita, M. Tang, S. Sugiura, S. Sato, T. Shirai, Suppression of prostate cancer growth by resveratrol in the transgenic rat for adenocarcinoma of prostate (TRAP) model., Asian Pac. J. Cancer Prev. 9 (2008) 7-14. 


\section{Figure legends:}

Figure 1. Schematic representation of rat prostate. It consists of four distinct lobes according to their relative position to urinary bladder: ventral (V), lateral (L), dorsal (D) and anterior (A) lobes.

Figure 2. Ultrasonographic monitoring of rat prostate during an assay of hormone and chemically-induced prostate carcinogenesis performed by our research team. Prostate lobes are visible around the urinary bladder (asterisks). Rat prostate immediately before the beginning of the experimental protocol $(A)$. A reduction of prostate volume was observed after flutamide administration for 21 consecutive days, this decrease was more evident on the ventral lobes (B). Six weeks after the $N$-methyl- $N$-nitrosourea (MNU) administration, an increase of the prostate dimensions was observed (C), with consequent compression of the neck of the urinary bladder (arrow) (D). The prostate volume continued increasing until the end of the experimental work, with a marked volume enhancement of the dorsal prostate lobes and the vesicular glands placed near the prostate lobes ( $E$ and $F$ ). Arrowheads in figures $D$ and $E$ indicate the prostate lobes. All images were obtained with the animal in supine position. Images $A, B, C$ and $E$ were obtained in transverse plane; images $\mathrm{D}$ and $\mathrm{F}$ were obtained in longitudinal plane.

Figure 3. Monitoring of rat prostate by Computed Tomography ( $\mathrm{A}$ and $\mathrm{B}$ ) and Magnetic Resonance Imaging ( $C$ and $D)$. It was evaluated the prostate of animals exposed to the protocol of prostate cancer induction ( $A$ and $C$ ) and the prostate of control animals ( $B$ and D). 
Figure 4. Influence of chemical carcinogen (MNU, N-methyl-N-nitrosourea) and hormonal stimulation (testosterone) on the induction of prostate cancer using a multistep protocol where the animals were submitted to a chemical castration (flutamide administration). Prostate cells' atrophy was observed after flutamide administration for 21 consecutive days. Cell hyperplasia was observed after a single injection of MNU and chronic exposure to testosterone for 18 weeks (23 weeks after the beginning of the protocol). The exposition of testosterone for 44 weeks (49 weeks after the beginning of the study) promoted the transition of cell hyperplasia to dysplasia, and finally the progression of carcinoma in situ to invasive carcinoma. 
Table 1. In vivo studies using MNU model of prostate cancer to assess the efficacy of several therapeutic strategies.

\begin{tabular}{|c|c|c|c|}
\hline \multicolumn{4}{|c|}{ MNU Model } \\
\hline Animal Strain & $\begin{array}{l}\text { Drugs or compounds evaluated } \\
\text { (classification) }\end{array}$ & Dose/Treatment & Therapeutic effects (Ref) \\
\hline \multirow{11}{*}{$\begin{array}{l}\text { Wistar- } \\
\text { Unilever }\end{array}$} & $\begin{array}{c}\text { Acticoa powder } \\
\text { (polyphenol) }\end{array}$ & Gavage ( 24 and $48 \mathrm{mg} / \mathrm{kg}$; 7 days/week) 2 wks before MNU & $\begin{array}{l}\text { Positive effects of acticoa powder at dose } \\
\text { of } 24 \mathrm{mg} / \mathrm{kg} \text { [103] }\end{array}$ \\
\hline & $\begin{array}{c}\text { Celocoxib } \\
\text { (non-steroidal anti-inflammatory drugs) }\end{array}$ & p.o. $(500 \mathrm{mg} / \mathrm{kg}) 21$ days after MNU for 52 wks & $\begin{array}{l}\text { Positive effects against prostate cancer } \\
\qquad[25]\end{array}$ \\
\hline & $\begin{array}{l}\text { Celecoxib and exisulind } \\
\text { (non-steroidal anti-inflammatory drugs) }\end{array}$ & $\begin{array}{c}\text { p.o. (celecoxib } 250 \text { or } 500 \text { ppm or exisulind } 500 \text { or } 1000 \text { ppm) } 21 \\
\text { days after MNU for } 52 \text { wks }\end{array}$ & $\begin{array}{l}\text { Positive effects of celocoxib plus exisulind } \\
\text { at low doses [104] }\end{array}$ \\
\hline & $\begin{array}{l}\text { Chronic dietary restriction } \\
\text { (caloric intake reduction) }\end{array}$ & $\begin{array}{l}\text { Dietary restriction ( ( } 0 \% \text { [ad libitum control], 15\%, or 30\%) } 2 \\
\text { weeks after MNU for } 12 \text { months }\end{array}$ & $\begin{array}{l}\text { No effect on the induction of prostate } \\
\text { cancer by reducing caloric intake [105] }\end{array}$ \\
\hline & \multirow{2}{*}{$\begin{array}{l}\text { Dehydroepiandrosterone (DHA) } \\
\text { (adrenal steroid) }\end{array}$} & p.o. ( $2000 \mathrm{mg} / \mathrm{kg}$ diet) 1,20 or 40 wks after $\mathrm{MNU}$ and 13 months & \multirow{2}{*}{$\begin{array}{l}\text { Inhibited prostate carcinogenesis in a } \\
\text { dose-related [19] }\end{array}$} \\
\hline & & p.o. (1000 or $2000 \mathrm{mg} / \mathrm{kg}$ diet) 1 wk before MNU for 13 months & \\
\hline & $\begin{array}{l}\mathrm{N} \text {-(4-Hydroxyphenyl)-all-trans-retinamide } \\
\text { (4-HPR) } \\
\text { (synthetic retinoid) }\end{array}$ & p.o. ( $1 \mathrm{mmol} / \mathrm{kg}$ diet for 450 days) on the day after MNU & No chemeopreventive effect [102] \\
\hline & $\begin{array}{l}\text { 9-cis-retinoic acid (9-cis-RA) } \\
\text { (natural metabolite of retinoic acid) }\end{array}$ & $\begin{array}{l}\text { Diet supplemented ( } 100 \mathrm{mg} / \mathrm{kg} \text { or } 50 \mathrm{mg} / \mathrm{kg} \text { diet) } 1 \text { week before } \\
\text { MNU for } 13 \text { months }\end{array}$ & $\begin{array}{l}\text { Chemeopreventive against prostate cancer } \\
\text { [89] }\end{array}$ \\
\hline & $\begin{array}{l}\text { Selenium and vitamin } \mathrm{E} \\
\text { (vitamins) }\end{array}$ & $\begin{array}{l}\text { p.o. (L-selenomethionine } 3 \text { or } 1.5 \mathrm{mg} / \mathrm{kg} \text { diet, vitamin } \mathrm{E}, 4 \text { or } 2 \\
\mathrm{mg} / \mathrm{kg} \text { diet and L-selenomethionine }+ \text { vitamin } \mathrm{E} 3+2 \mathrm{mg} / \mathrm{kg} \text { or } \\
3+500 \mathrm{mg} / \mathrm{diet} \text { ) } 1 \text { wk after MNU and for } 13 \text { months }\end{array}$ & $\begin{array}{l}\text { No effects of the compounds alone or } \\
\text { together [24] }\end{array}$ \\
\hline & $\begin{array}{l}\text { Soy isoflavone mixture PTI G- } 2535 \text { and a } \\
\text { soy-derived protease inhibitor (BBIC) } \\
\text { (soy isoflavones/protease inhibitor) }\end{array}$ & $\begin{array}{l}\text { p.o. }(0,200 \text { or } 2000 \mathrm{mg} / \mathrm{kg} \text { diet of PTI G-2535 or BBIC) } 1 \text { wk after } \\
\text { MNU for } 13 \text { months }\end{array}$ & $\begin{array}{c}\text { The combination of PTI G-2535+ BBIC was } \\
\text { more effective in prostate cancer } \\
\text { prevention than the compounds alone } \\
{[106]}\end{array}$ \\
\hline & $\begin{array}{l}\gamma \text {-tocopherol } \\
\text { (vitamin) }\end{array}$ & p.o. $(20 \mathrm{mg} / \mathrm{kg})$ for $16 \mathrm{wks}$ & $\begin{array}{l}\text { Protected against the development of } \\
\text { cancer [107] }\end{array}$ \\
\hline
\end{tabular}




\begin{tabular}{|c|c|c|c|}
\hline & $\begin{array}{l}\text { Tomato Powder and Lycopene } \\
\text { (spray-dried product made from heat- } \\
\text { processed tomato paste/water-dispersible } \\
\text { lycopene beadlets) }\end{array}$ & $\begin{array}{l}\text { Diet supplemented (Lycopene } 2.5 \mathrm{mg} / \mathrm{kg} \text { diet and tomato powder } \\
\qquad 100 \mathrm{~g} / \mathrm{kg} \text { diet) }\end{array}$ & $\begin{array}{l}\text { Tomato powder but not lycopene inhibited } \\
\text { prostate carcinogenesis [108] }\end{array}$ \\
\hline \multirow{3}{*}{$\begin{array}{l}\text { Sprague- } \\
\text { Dawley }\end{array}$} & $\begin{array}{l}\text { Diallyl disulfide } \\
\text { (component of garlic) }\end{array}$ & p.o. (150 mg/kg b.w.; 2 times/wk for 16 wks) & Inhibited prostate carcinogenesis [109] \\
\hline & $\begin{array}{l}\text { Fluasterone } \\
\text { (dehydroepiandrosterone analog) }\end{array}$ & PO (2000 and $1000 \mathrm{mg} / \mathrm{kg}$ diet) $1 \mathrm{wk}$ before MNU, for 13 months & $\begin{array}{l}\text { Suppressed prostate cancer induction } \\
\qquad[110]\end{array}$ \\
\hline & $\begin{array}{l}\text { Zinc chloride } \\
\text { (trace element) }\end{array}$ & $\begin{array}{l}\text { d.w. (100 ppm } 3 \text { times/wk for } 20 \text { wks) } 1 \text { wk before administration } \\
\text { of initial dose of testosterone propionate; administration for } 20 \\
\text { wks }\end{array}$ & Reduced tumor incidence [21] \\
\hline Albino wistar & $\begin{array}{l}\text { Calcitriol } \\
\text { (vitamin D metabolite) }\end{array}$ & $\begin{array}{c}\text { i.p. }(0.5 \mu \mathrm{g} / \mathrm{kg} \text { b.w. } 3 \text { times/wk) } 1 \mathrm{wk} \text { before administration of } \\
\text { cyproterone acetate and for } 16 \mathrm{wks}\end{array}$ & Chemeopreventive activity [22] \\
\hline Wistar & $\begin{array}{l}\text { Monascus cursory extraction (MCE) } \\
\text { (red mold rice metabolite) }\end{array}$ & p.o. $(0.2 \%$ or $0.5 \%) 21$ days after MNU for 52 wks & $\begin{array}{l}\text { Reduced incidence and size of tumors } \\
\text { [111] }\end{array}$ \\
\hline \multirow{6}{*}{$\begin{array}{l}\text { Lobund- } \\
\text { Wistar }\end{array}$} & \multirow{2}{*}{$\begin{array}{l}\text { Genistein } \\
\text { (phytoestrogen component of soy) }\end{array}$} & $\begin{array}{l}\text { p.o. ( } 250 \mathrm{mg} / \mathrm{kg} / \mathrm{diet}) \text { from birth until } 35 \text { days or start at } 90 \text { days } \\
\text { of age, } 20 \text { days after cancer initiation, until } 11 \text { months or from } \\
\text { birth throughout life }\end{array}$ & $\begin{array}{l}\text { Inhibited prostate cancer was more } \\
\text { effective by life time exposure[112] }\end{array}$ \\
\hline & & $\begin{array}{c}\text { p.o. (25 and } 250 \mathrm{mg} / \mathrm{kg} / \mathrm{diet} \text { ) start at conception and continued } \\
\text { until euthanasia }\end{array}$ & Protective effects of lifetime dietary [113] \\
\hline & $\begin{array}{l}\text { Glutaraldehyde-fixed tumor (GFT) cell } \\
\text { vaccine }\end{array}$ & $\begin{array}{l}\text { Vaccination when tumors were first palpated and weekly until the } \\
\text { rats became clinically debilitated }\end{array}$ & $\begin{array}{l}\text { Tumor regression and reduction of } \\
\text { metastases [114] }\end{array}$ \\
\hline & \multirow{2}{*}{$\begin{array}{l}\text { Linomide } \\
\text { (quinoline-3-carboxamide) }\end{array}$} & $\begin{array}{l}\text { d.w. (0-25 mg/kg daily) after testosterone implantation and for } 12 \\
\text { months }\end{array}$ & $\begin{array}{l}\text { Inhibited } 60 \% \text { of incidence of prostate } \\
\text { cancer at maximum dose [115] }\end{array}$ \\
\hline & & $\begin{array}{c}\text { i.p. ( } 100 \mathrm{mg} / \mathrm{kg} \text { b.w. daily) or in d.w. ( } 1 \mathrm{mg} / 1 \mathrm{ml} \text { water) when } \\
\text { small palpable tumors }(0.5-\mathrm{cm} \text { diameter) were detected until the } \\
\text { tumors reached } 3-4 \mathrm{~cm} \text { in diameter }\end{array}$ & $\begin{array}{l}\text { Minimal therapeutic benefit on tumor } \\
\text { development [116] }\end{array}$ \\
\hline & $\begin{array}{l}\mathrm{N} \text {-(4-Hydroxyphenyl)-all-trans-retinamide } \\
\text { (4-HPR) } \\
\text { (synthetic retinoid) }\end{array}$ & p.o. (1mmol/kg diet) after 7 months MNU & Prevented prostate cancer [117] \\
\hline
\end{tabular}




\begin{tabular}{|c|c|c|}
\hline $\begin{array}{c}\text { Tamoxifen, N-(4-Hydroxyphenyl)retinamide } \\
\text { (4-HPR) and la,25-dihydroxy-16-ene-23- } \\
\text { yne-26,27-hexafluorocholecalciferol (Ro24- } \\
5531 \text { ) } \\
\text { (selective estrogen receptor modulators } \\
\text { synthetic retinoid; Vitamin D analogue) }\end{array}$ & $\begin{array}{l}\text { p.o. (2.5 or } 1.25 \mathrm{nmol} / \mathrm{kg} \text { diet of Ro245331, } 2 \text { or } 1 \mathrm{nmom} / \mathrm{kg} \text { diet } \\
\text { of } 4-\mathrm{HPR} \text { and } 5 \text { or } 0.5 \mathrm{mg} / \mathrm{kg} \text { diet of tamoxifen) }\end{array}$ & Reduced tumors development [91] \\
\hline
\end{tabular}

p.o.: per os; wks: weeks; d.w.: drinking water; i.p.: intraperitoneal injection; b.w. body weight. 
Table 1. In vivo studies with DMAB model to study different therapeutic approaches for prostate cancer.

\begin{tabular}{|c|c|c|c|}
\hline \multicolumn{4}{|c|}{ DMAB Model } \\
\hline Animal Strain & $\begin{array}{l}\text { Drugs or compounds evaluated } \\
\text { (classification) }\end{array}$ & Dose/Treatment & Therapeutic effects (Ref) \\
\hline \multirow{10}{*}{ Fischer 344} & $\begin{array}{c}\text { Bicalutamide } \\
\text { (antiandrogen) } \\
\end{array}$ & p.o. $(30 \mathrm{mg} / \mathrm{kg} / \mathrm{diet} 3$ times $/ \mathrm{wk}) 40 \mathrm{wks}$ after DMAB for $14 \mathrm{wks}$ & $\begin{array}{l}\text { Decrease prostate cancer if treatment } \\
\text { started in later period of disease [118] }\end{array}$ \\
\hline & $\begin{array}{l}\text { Cadmium } \\
\text { (heavy metal) }\end{array}$ & $\begin{array}{c}\text { i.m. ( } 30 \mu \mathrm{mol} / \mathrm{kg} \text { b.w. and } 10 \mu \mathrm{mol} / \mathrm{kg} \text { b.w. on the } 1^{\text {st }} \text { day; or } 30 \\
\mu \mathrm{mol} / \mathrm{kg} \text { b.w. and } 10 \mu \mathrm{mol} / \mathrm{kg} \text { b.w. after DMAB; or } 10,20 \text { and } \\
\mu \mathrm{mol} / \mathrm{kg} \text { b.w. at wk } 40 ; \text { or } 10 \mu \mathrm{mol} / \mathrm{kg} \text { b.w. at wk } 20 \text { and then } 5 \\
\mu \mathrm{mol} / \mathrm{kg} \text { b.w. at wk } 30,40 \text { and } 50 .)\end{array}$ & Promoted prostate cancer [27] \\
\hline & $\begin{array}{l}\text { Cholesterol, saponin, clofibrate } \\
\text { (sterol; glycosides; fibrate) }\end{array}$ & $\begin{array}{l}\text { p.o. ( } 1 \% \text { and } 2 \% \text { of cholesterol or } 0.3 \% \text { clofibrate) and SC ( } 1 \mathrm{mg} \\
\text { saponin) after DMAB for } 40 \mathrm{wks}\end{array}$ & $\begin{array}{l}\text { No effects of cholesteremia were observed } \\
\text { [31] }\end{array}$ \\
\hline & $\begin{array}{c}\text { Fat diets (corn oil, beef tallow and } \\
\text { perilla oil) } \\
\text { (polyunsaturated fatty acids) }\end{array}$ & $\begin{array}{l}\text { p.o. ( } 20 \% \text { of corn oil, beef tallow or perilla oil/diet) from the } \\
\text { beginning of experiment during } 60 \mathrm{wks}\end{array}$ & $\begin{array}{l}\text { Promotion of prostate carcinogenesis by } \\
\text { beef tallow, but not corn oil or perilla oil } \\
\text { [119] }\end{array}$ \\
\hline & $\begin{array}{c}\text { Finasteride and casodex } \\
\text { (5-alpha reductase inhibitor; } \\
\text { antiandrogen) }\end{array}$ & $\begin{array}{l}\text { p.o. ( } 5 \text { or } 15 \mathrm{mg} / \mathrm{kg} / \text { diet of finasteride } 2 \text { times/wk and } 15,30 \text { or } 50 \\
\mathrm{mg} / \mathrm{kg} / \text { diet casodex } 3 \text { times/wk), } 20 \text { wks after DMAB for } 40 \text { wks }\end{array}$ & $\begin{array}{l}\text { Inhibited prostate cancer in a dose- } \\
\text { dependent manner [120] }\end{array}$ \\
\hline & $\begin{array}{l}\text { Genistin and daidzin } \\
\quad \text { (isoflavones) }\end{array}$ & p.o. $(0,1 \%$ genistin and $0,1 \%$ daidzin/diet) after DMAB for 40 wks & $\begin{array}{c}\text { Reduced the numbers of ventral prostate } \\
\text { carcinomas and decrease in incidence with } \\
\text { both compounds [121] }\end{array}$ \\
\hline & $\begin{array}{c}\text { Indomethacin } \\
\text { (nonsteroidal anti-inflammatory } \\
\text { drug) }\end{array}$ & d.w. (20 ppm) after DMAB for 37 wks & No inhibited tumor development [122] \\
\hline & $\begin{array}{l}\text { p-nonylphenol (NP) } \\
\text { (alkylphenols) }\end{array}$ & p.o. $(0,25,250$ or 2000 ppm/diet) from 3 wks of rat age for 3 wks & $\begin{array}{c}\text { No modulating effects on prostate } \\
\text { carcinogenesis late neonatal treatment with } \\
\text { NP [90] }\end{array}$ \\
\hline & $\begin{array}{c}4-n \text {-octylphenol } \\
\text { (estrogenic compound) }\end{array}$ & p.o. $(0,10$ or $100 p p m) 1$ wk after DMAB for 20 wks & No effects were observed [55] \\
\hline & 4-tert-octylphenol (tOP) and benzyl & p.o. (100/10 ppm of tOP or $100 / 10$ ppm of BBP/diet) & No effects were observed [123] \\
\hline
\end{tabular}




\begin{tabular}{|c|c|c|}
\hline $\begin{array}{c}\text { butyl phthalate (BBP) } \\
\text { (estrogenic compounds) }\end{array}$ & & \\
\hline $\begin{array}{c}\text { Silymarin } \\
\text { (polyphenolic flavonoid antioxidant) }\end{array}$ & $\begin{array}{l}\text { p.o. (100 or } 500 \text { ppm/diet) 1wk after the last dosing of DMAB for } 40 \\
\text { wks }\end{array}$ & Chemeopreventive ability [124] \\
\hline $\begin{array}{l}\text { Soybean isoflavone mixture ( } 74 \% \\
\text { genistein and } 21 \% \text { daidzein) }\end{array}$ & p.o. (100 and $400 \mathrm{ppm} /$ diet) for $50 \mathrm{wks}$ & $\begin{array}{l}\text { Suppressed the development of } \\
\text { adenocarcinoma [20] }\end{array}$ \\
\hline $\begin{array}{c}\text { Testosterone propionate (TP) and } \\
\text { diethylstilbestrol (DES) } \\
\text { (anabolic steroid; synthetic, } \\
\text { nonsteroidal estrogen) }\end{array}$ & $\begin{array}{l}\text { Silastic tubes ( } 40 \mathrm{mg} \text { of TP and } 10 \mathrm{mg} \text { of DES) } 20 \text { wks after DMAB for } \\
30 \text { days then removed for } 10 \text { days repeated } 7 \text { times for } 40 \text { weeks }\end{array}$ & $\begin{array}{l}\text { Inhibited prostate cancer development by } \\
\text { combination of TP and DES [125] }\end{array}$ \\
\hline
\end{tabular}

p.o.: per os; wks: weeks; i.m.: intramuscular injection; b.w.: body weight; s.c.: subcutaneous injection 
Table 1. In vivo studies using PhiP model to assess the efficacy of several compounds on prostate cancer prevention.

\begin{tabular}{|c|c|c|c|}
\hline \multicolumn{4}{|c|}{ PhiP model } \\
\hline Animal Strain & $\begin{array}{l}\text { Drugs or compounds evaluated } \\
\text { (classification) }\end{array}$ & Dose/Treatment & Therapeutic effects (Ref) \\
\hline \multirow{4}{*}{ Fischer 344} & $\begin{array}{l}\text { Fujiflavone (commercial } \\
\text { isoflavone supplement) }\end{array}$ & p.o. $(0.25 \%) 10$ wks after PhIP for 50 wks & Inhibited prostate cancer [61] \\
\hline & $\begin{array}{l}\text { Lycopene and curcumin } \\
\text { (carotenoid pigment; } \\
\text { component of rhizomatous } \\
\text { herbaceous perennial plant ) }\end{array}$ & $\begin{array}{c}\text { p.o. (45 ppm/diet of lycopne, } 500 \mathrm{ppm} / \text { diet of curcumin or lycopne } \\
+ \text { + curcumin) after PhiP for } 50 \mathrm{wks}\end{array}$ & $\begin{array}{l}\text { No effects on prostate tumor development } \\
\text { with the compounds alone or together [62] }\end{array}$ \\
\hline & $\begin{array}{c}\text { Nobiletin ( } 5,6,7,8,3^{\prime}, 4^{\prime}- \\
\text { hexamethoxy flavones) } \\
\text { (polymethoxy-flavnoid extract } \\
\text { from citrus fruits) }\end{array}$ & p.o. $(0.05 \%) 16$ wks of rat age to 66 wks of rat age & Inhibited prostate cancer [56] \\
\hline & $\begin{array}{l}\text { Whole tomato powder }+ \\
\text { broccoli powder } \\
\text { (fruit; vegetable) }\end{array}$ & p.o. ( $10 \%$ of freez dried powders) for 20 wks & $\begin{array}{l}\text { Reduced and prevented prostate cancer } \\
\qquad[59]\end{array}$ \\
\hline
\end{tabular}

p.o.: per os; wks: weeks 
Table 1. In vivo prostate cancer chemeopreventive studies using the Dunning model sublines.

\begin{tabular}{|c|c|c|c|}
\hline \multicolumn{4}{|c|}{ Dunning model } \\
\hline \multicolumn{4}{|c|}{ Cell line: Dunning R3327-AT-1 model } \\
\hline Animal Strain & $\begin{array}{l}\text { Drugs or compounds evaluated } \\
\text { (classification) }\end{array}$ & Dose/Treatment & Therapeutic effects (Ref) \\
\hline \multirow{3}{*}{ Copenhagen } & Physical activity & $\begin{array}{l}\text { TR (60-min } 5 \text { day/wk for } 7 \text { wks) } 7-10 \text { days after tumor } \\
\text { inoculation }\end{array}$ & $\begin{array}{c}\text { Exercise training increased tumor } \\
\text { microvascular Po2 and reduced tumor } \\
\text { hypoxia [72] }\end{array}$ \\
\hline & $\begin{array}{l}\text { Pomegranate juice and exercise } \\
\text { training }\end{array}$ & $\begin{array}{c}\text { p.o. }(15 \mu \mathrm{l} \text { pomegranate juice } 5 \text { days } / w k \text { ) and TR ( } 40 \mathrm{~min} 5 \\
\text { days/wk for } 2 \text { wks) } 15 \text { days after cell line inoculation or p.o. ( } 750 \\
\mu \text { l pomegranate juice) + TR ( } 60 \text { min } 5 \text { days/wk } 2 \text { wks) }\end{array}$ & $\begin{array}{l}\text { Decreased prostate tumor proliferation by } \\
\text { treadmill running, but the combination of } \\
\text { the two approaches was not efficient when } \\
\text { compared with the treatments conducted } \\
\text { separately [126] }\end{array}$ \\
\hline & $\begin{array}{c}\text { Soy protein isolate and } \\
\text { conjugated linoleic acid } \\
\text { (isoflavone-rich protein isolate } \\
\text { from genistein; natural positional } \\
\text { isomer of linoic acid) } \\
\end{array}$ & $\begin{array}{l}\text { p.o. }(5,10 \text { and } 20 \% / \text { diet of soy protein isolate and } 0.5 \text { and } \\
1 \% / \text { diet of conjugated linoleic acid) for } 35 \mathrm{wks}\end{array}$ & $\begin{array}{l}\text { No inhibitory effects of the compounds } \\
\text { alone or together were observed on tumor } \\
\text { growth and development [127] }\end{array}$ \\
\hline \multicolumn{4}{|c|}{ Cell line: Dunning R3327H model } \\
\hline \multirow{4}{*}{ Copenhagen } & $\begin{array}{l}\text { Lycopene, selenium (in the form } \\
\text { of methylselenocysteine) and } \\
\text { vitamin } E \text { ( } \gamma \text {-tocopherol) } \\
\text { (vitamins) }\end{array}$ & $\begin{array}{l}\text { Diet supplemented ( } 250 \mathrm{mg} / \mathrm{kg} \text { of lycopene beadlets, } 1 \mathrm{mg} / \mathrm{kg} \text { of } \\
\text { selenium and } 200 \mathrm{mg} / \mathrm{kg} \text { vitamin E) 4-6 weeks before tumor } \\
\text { inoculation for } 22-24 \text { weeks }\end{array}$ & $\begin{array}{c}\text { Reduced growth of prostate tumor by } \\
\text { selenium, but not lycopene or vitamin E } \\
\text { [128] }\end{array}$ \\
\hline & Hyperthermia & $\begin{array}{c}\text { Hyperthermia treatments ( } 46.5 \circ \mathrm{C} \text { twice) for } 2 \text { hours when the } \\
\text { tumor volume reached } 0.5 \text { to } 2.0 \mathrm{~cm}^{3}\end{array}$ & Death of tumor cells [129] \\
\hline & $\begin{array}{c}\text { PNU } 157706 \text { ((N-(1,1,1,3,3,3- } \\
\text { hexafluorophenylpropyl)-3-oxo-4- } \\
\text { aza-5a-androst-1-ene-17b- } \\
\text { carboxamide)) and flutamide } \\
\text { (5a-reductase inhibitor ;non- } \\
\text { steroidal antiandrogen }\end{array}$ & $\begin{array}{c}\text { Oral ( } 10 \mathrm{mg} / \mathrm{kg} / \mathrm{day} \text { of PNU } 157706 \text { and } 1 \text { or } 5 \mathrm{ml} / \mathrm{kg} / \mathrm{day} \text { of } \\
\text { flutamide } 6 \text { days/week) for } 9 \text { weeks }\end{array}$ & $\begin{array}{l}\text { Inhibited prostate cancer of both } \\
\text { compounds [130] }\end{array}$ \\
\hline & & & \\
\hline
\end{tabular}




\begin{tabular}{|c|c|c|c|}
\hline F1 hybrid & $\begin{array}{l}\text { Cyclophosphamide, } \\
\text { ketoconazole, aclacinomycin-A, } \\
\text { methotrexate and methotrexate-- } \\
\text { 5-Fluorouracil } \\
\text { (alkylating agente antifungal } \\
\text { drug; antracycline; chemotherapy } \\
\text { agent; antimetabolite) }\end{array}$ & $\begin{array}{l}\text { Exp1: i.p. (100 mg/cyclophosphamide once every } 3 \text { to } 4 \mathrm{wks} \text { and } \\
7.5 \mathrm{mg} / \mathrm{kg} \text { of methotrexate followed in } 90 \mathrm{~min} \text { by } 50 \mathrm{mg} / \mathrm{kg} \text { of } 5- \\
\text { fluorouracil once each wk for } 8 \mathrm{wks} \text {; Exp2: i.p. ( } 100 \mathrm{mg} / \mathrm{kg} \text { of } \\
\text { methotrexate once each wk for } 6 \mathrm{wks}, 8 \mathrm{mg} / \mathrm{kg} \text { of aclacinomycin- } \\
\text { A once wk for } 4 \text { wks and p.o. ( } 60 \mathrm{mg} / \mathrm{kg} \text { of ketoconazole } 5 \\
\text { times } / \mathrm{wk} \text { for } 6 \mathrm{wks} \text { ) }\end{array}$ & $\begin{array}{l}\text { Significant suppression of tumor growth } \\
\text { by Aclacinomycin-A and ketoconazole } \\
\qquad[131]\end{array}$ \\
\hline $\begin{array}{l}\text { Copenhagen x Fischer } \\
\text { F1 }\end{array}$ & $\begin{array}{c}\text { Estramustine } \\
\text { phosphate+radiation treatment } \\
\text { (alkylating antineoplastic agente) }\end{array}$ & $\begin{array}{c}\text { s.c. }(360 \mu \mathrm{g} / \mathrm{day} / \mathrm{rat}) 3 \text { months after tumor inoculation and } 1 \text { day } \\
\text { after radiation for } 2 \mathrm{wks}\end{array}$ & $\begin{array}{c}\text { Decreased prostate cancer volume and } \\
\text { estramustine phosphate potentiated } \\
\text { irradiation [132] }\end{array}$ \\
\hline $\begin{array}{l}\text { Copenhagen x Fischer } \\
\text { F2 }\end{array}$ & $\begin{array}{l}\text { 6-Methylene-4-pregnene-3,20- } \\
\text { dione (6MP) + castration } \\
\text { (inhibitor of } 5 \alpha \text {-reductase) }\end{array}$ & $\begin{array}{c}\text { s.c. }(10,20 \text { and } 40 \mathrm{mg} / \mathrm{kg} \text { b.w. of } 6 \mathrm{MP}) \text { or castration }+40 \mathrm{mg} / \mathrm{kg} \\
\text { b.w. of } 6 \mathrm{MP}+0.1 \mathrm{mg} \text { of testosterone propionate } 3 \text { months after } \\
\text { tumor inoculation for } 4 \text { wks }\end{array}$ & $\begin{array}{c}\text { Reduced tumor growth in castrated and } \\
\text { testosterone supplemented animals. 6MP } \\
\text { may represent an alternative for } \\
\text { castration [133] }\end{array}$ \\
\hline \multicolumn{4}{|c|}{ Cell line: Dunning R3327-AT-2 model } \\
\hline Copenhagen & $\begin{array}{l}\text { Laser interstitial } \\
\text { thermotherapy (LITT) }\end{array}$ & LITT (980nm diode laser for $75 \mathrm{~s}$ ) after $3 \mathrm{wks}$ of tumor inoculation & Induced tumor necrosis [134] \\
\hline Copenhagen x Fisher & $\begin{array}{l}\text { High-intensity focused } \\
\text { ultrasound (HIFU) combined } \\
\text { with chemotherapy }\end{array}$ & $\begin{array}{c}\text { HIFU alone or with } 2 \text { chemotherapy agentes ( } 4 \mathrm{mg} / \mathrm{kg} \text { paclitaxel } \\
\text { s.c. and } 15 \mathrm{mg} / \mathrm{kg} \text { estramustine phosphate i.p.) after } 15 \text { days } \\
\text { tumor inoculation for } 5 \text { days }\end{array}$ & $\begin{array}{l}\text { Inhibited tumor development by combined } \\
\text { treatment [135] }\end{array}$ \\
\hline \multicolumn{4}{|c|}{ Cell line:Dunning R3327-MAT-Ly-Lu model } \\
\hline \multirow{4}{*}{ Male Copenhagen rat } & $\begin{array}{c}\text { Brahma rasayana } \\
\text { (herbal tonic) }\end{array}$ & $\begin{array}{c}\text { p.o. }(1,250 \text { and } 1.5 \mathrm{mg} / \mathrm{kg} \text { b.w. daily) } 2 \text { days after tumor } \\
\text { inoculation for } 5 \text { wks }\end{array}$ & Reduced tumor incidence [136] \\
\hline & $\begin{array}{c}\text { Calcitriol and EB1089 (analogue } \\
\text { of } 1,25(\mathrm{OH}) 2 \mathrm{D}) \\
\text { (steroid hormone) }\end{array}$ & $\begin{array}{l}\text { i.p. }(0.5 \mu \mathrm{g} / \mathrm{kg} \text { calcitriol or } 0.5 \mu \mathrm{g} / \mathrm{kg} \text { EB1089 } 3 \text { times } / \mathrm{wk}) 7 \mathrm{days} \\
\text { before tumor implantation until the tumors grew to } 10 \mathrm{ml}\end{array}$ & $\begin{array}{l}\text { Both compoundslihibited prostate cancer } \\
\text { metastasis [137] }\end{array}$ \\
\hline & $\begin{array}{c}\text { Doxycycline (DC) and non- } \\
\text { antimicrobial chemically } \\
\text { modified tetracycline (CMT-3) } \\
\text { (tetracycline) }\end{array}$ & $\begin{array}{l}\text { p.o. ( } 40 \mathrm{mg} / \mathrm{kg} \mathrm{DC} \text { and CMT-3 daily) } 5 \text { days after tumor } \\
\text { implantation until tumors reached a volume }>10 \mathrm{ml}\end{array}$ & $\begin{array}{l}\text { Reduced tumor incidence and metastasis } \\
\qquad[138]\end{array}$ \\
\hline & 1,25-dihydroxycholecalciferol & s.c. $(0,1 \mathrm{ml} 3$ times $/ \mathrm{wk})$ for $3 \mathrm{wks}$ & Inhibititedtumor volume and reduced the \\
\hline
\end{tabular}




\begin{tabular}{|c|c|c|}
\hline $\begin{array}{c}(1,25-d 3) \\
\left.\text { (vitamin } D_{3}\right)\end{array}$ & & number and size of lung metastases [139] \\
\hline $\begin{array}{l}\text { 1,25-dihydroxyvitamin D3 } \\
\text { (calcitriol) and two analogues } \\
\text { (EB1089 and CB1093) } \\
\text { (steroid hormone) }\end{array}$ & $\begin{array}{c}\text { i.p. }(1 \mu \mathrm{g} / \mathrm{kg} \text { calcitriol or } 2.5 \mu \mathrm{g} / \mathrm{kg} \text { analogues } 5 \text { days } / \mathrm{wk}) 1 \text { day after } \\
\text { tumor inoculation }\end{array}$ & $\begin{array}{l}\text { All compounds inhibited tumor growth } \\
\qquad[140]\end{array}$ \\
\hline Physical activity & TR (5 minutes/day) after 21 days tumor inoculation for 5 days & Increased tumor oxygenation [73] \\
\hline $\begin{array}{l}\text { Gabapentin (1-(aminomethyl) } \\
\text { cyclohexane aceit acid) } \\
\text { (analgesic) }\end{array}$ & $\begin{array}{l}\text { p.o. ( 4.6, } 9.1 \text { and } 16.8 \mu \mathrm{g} / \mathrm{kg} / \text { diet daily) } 48 \mathrm{~h} \text { after initial } \\
\text { inoculation for } 21 \text { days }\end{array}$ & $\begin{array}{l}\text { No effect on prostate tumor development } \\
\qquad[141]\end{array}$ \\
\hline $\begin{array}{c}\text { Estramustine and 9- } \\
\text { aminocamptothecin (9-AC) } \\
\text { (alkylating antineoplastic } \\
\text { agente; water-insoluble } \\
\text { camptothecin derivative) }\end{array}$ & $\begin{array}{l}\text { i.p. }(10 \mathrm{mg} / \mathrm{kg} / \text { day estramustine on days } 4 \text { to } 13) \text { and s.c. (9-AC on } \\
\text { days } 4 \text { to } 13) \text { for } 14 \text { days }\end{array}$ & Inhibited prostate cancer growth [142] \\
\hline $\begin{array}{l}\text { Estramustine and colchicines } \\
\text { (alkylating antineoplastic } \\
\text { agent; alkaloid) }\end{array}$ & $\begin{array}{l}\text { i.p. ( } 10.1 \mathrm{mg} / \mathrm{kg} \text { estramustine and } 0.1 \mathrm{mg} / \mathrm{kg} \text { colchicine) on days 4- } \\
\qquad 13\end{array}$ & $\begin{array}{l}\text { No interactions of compounds inhibited } \\
\text { prostate cancer cell growth [143] }\end{array}$ \\
\hline $\begin{array}{l}\text { Magnetic Fluid Hyperthermia } \\
\qquad(\mathrm{MFH})\end{array}$ & $\begin{array}{l}\text { Magnetic fluids (injections of } 400 \mu \mathrm{l} \text { ) and MFH (frequency } 100 \mathrm{~Hz} \\
\text { and field strength } 0-18 \mathrm{kA} / \mathrm{m} \text { ) during } 45 \mathrm{~min} 20 \text { days after tumor } \\
\text { inoculation }\end{array}$ & Inhibited growth tumor [74] \\
\hline $\begin{array}{l}\text { Mix of estramustine, etoposide } \\
\text { and taxol } \\
\text { (alkylating antineoplastic } \\
\text { agente; semisynthetic } \\
\text { derivative of podophyllotoxin; } \\
\text { antineoplastic drug) }\end{array}$ & $\begin{array}{c}\text { i.p. (10 mg/kg/day estramustine on days } 4 \text { to } 13 \text { and } \\
50 \mathrm{mg} / \mathrm{m} 2 / \text { day etoposide on days } 4 \text { to } 13) \text { and i.v. }\left(135 \mathrm{mg} / \mathrm{m}^{2}\right. \\
\text { taxol on days } 4 \text { to } 10)\end{array}$ & Inhibited prostate cancer cell growth [144] \\
\hline $\begin{array}{l}\text { Nucleoside analogue } \mathrm{BCH}- \\
4556 \text { [ } \beta \text {-L-(-)-dioxolane- } \\
\text { cytidine] }\end{array}$ & $\begin{array}{c}\text { i.p. ( } 75 \mathrm{mg} / \mathrm{kg} 2 \text { times/day) soon after tumor inoculation or } 3 \text { days } \\
\text { after for } 6 \text { days or IP ( } 25 \mathrm{mg} / \text { day or } 75 \mathrm{mg} / \text { day } 2 \text { times/day) } 8 \text { days } \\
\text { after tumor inoculation for } 6 \text { days }\end{array}$ & $\begin{array}{l}\text { The maximum dose prevented tumor } \\
\text { growth [145] }\end{array}$ \\
\hline Paclitaxel (antineoplastic drug) & $\begin{array}{l}\text { Intratumorally injection (polymer loaded with paclitaxel in total of } \\
250 \mu \text { l of the suspension) } 1 \text { time or i.p. } 4 \text { mo of paclitaxel) every } 3 \\
\text { days for } 35 \text { days }\end{array}$ & $\begin{array}{l}\text { Polymeric formulation releasing paclitaxel } \\
\text { reduced the tumor mass and metastases } \\
\qquad[146]\end{array}$ \\
\hline
\end{tabular}


Tamoxifen and vinblastine (selective estrogen receptor modulator; natural alkaloid) Thermotherapy using magnetic nanoparticles combined with external radiation d.w. (100nM Tamoxifen daily)and IV (1\% vinblastine on days 3 and 10) for 14 days

Magnetic fluid ( 200-400 $\mu$ l) and MFH (frequency $100 \mathrm{~Hz}$ and field

strength 0-18 kA/m); External radiation (2x10 Gy, 2x20 Gy or $2 \times 30$ Gy) 20 days after tumor inoculation
Combined compounds inhibited the prostate tumor growth [147]

Combined treatment with the radiation dose of $20 \mathrm{~Gy}$ inhibited tumor growth [148]

TR: treadmill running; p.o.: per os; wks: weeks; i.p.: intraperitoneal injection; d.w.: drinking water; s.c.: subcutaneous injection; i.v.: intravenous injection 
Table 1. In vivo studies using transgenic rats to evaluate the effect of various compounds in prostate cancer studies.

\begin{tabular}{|c|c|c|c|}
\hline \multicolumn{4}{|c|}{ Transgenic rats model } \\
\hline Animal Strain & Drugs or compounds evaluated & Dose/Treatment & Therapeutic effects (Ref) \\
\hline \multirow{11}{*}{$\begin{array}{l}\text { Trangenic rats with a } \\
\text { Sprague-Dawley genetic } \\
\text { background }\end{array}$} & $\begin{array}{c}\text { Apocynin } \\
\text { (inhibitor of NADPH oxidase) }\end{array}$ & d.w. $(100$ or $500 \mathrm{mg} / \mathrm{mL})$ at $6 \mathrm{wks}$ of age for $8 \mathrm{wks}$ & $\begin{array}{l}\text { Suppressed the progression of prostate } \\
\text { carcinogenesis [149] }\end{array}$ \\
\hline & $\begin{array}{c}\text { Arctiin } \\
\text { (phytoestrogen lignan) }\end{array}$ & p.o. $(0.1,0.002$ or $0.004 \%)$ for $18 \mathrm{wks}$ & No effects wereobserved [150] \\
\hline & $\begin{array}{c}\text { Atrazine } \\
\text { (herbicide of the triazine class) }\end{array}$ & p.o. (500 or 1000 ppm/diet) for 13 weeks & $\begin{array}{c}\text { Slight inhibition of prostate carcinogenesis } \\
\text { by high dose [151] }\end{array}$ \\
\hline & $\begin{array}{l}\text { Fermented brown rice and rice } \\
\text { bran with Aspergillus oryzae }\end{array}$ & p.o (5 or $10 \% /$ diet) at 6 wks of age for 15 wks & $\begin{array}{l}\text { Suppressed the progression of prostate } \\
\text { carcinogenesis (54) }\end{array}$ \\
\hline & $\begin{array}{l}\text { Finasteride and flutamide } \\
\text { (5-alpha reductase; non } \\
\text { steroidal antiandrogen) }\end{array}$ & $\begin{array}{c}\text { Gavage ( Finasteride } 10 \mathrm{mg} / \mathrm{kg} \text { and flutamide } 5 \text { or } 20 \mathrm{mg} / \mathrm{kg} \text { ) } 5 \\
\text { times/ week for } 2,5 \text { and } 7 \text { weeks }\end{array}$ & $\begin{array}{l}\text { Suppressed prostate cancer development } \\
\qquad[26]\end{array}$ \\
\hline & $\begin{array}{l}\text { Genistein and resveratrol } \\
\text { (phytoestrogens) }\end{array}$ & $\begin{array}{l}\text { p.o. ( } 250 \mathrm{mg} / \mathrm{kg} / \text { diet genistein and } 250 \mathrm{mg} / \mathrm{kg} / \text { diet reveratrol or } \\
83 \mathrm{mg} / \mathrm{kg} / \mathrm{diet} \text { genistein }+83 \mathrm{mg} / \mathrm{kg} / \text { diet resveratrol) at birth for } \\
12 \mathrm{or} 30 \mathrm{wks}\end{array}$ & $\begin{array}{c}\text { Compounds alone or in combination } \\
\text { suppressed prostate cancer development } \\
{[152]}\end{array}$ \\
\hline & $\begin{array}{l}\text { Leuprorelin acetate } \\
\text { (luteinizing hormone-releasing } \\
\text { hormone agonist) }\end{array}$ & s.c. $(0.28$ and $2.8 \mathrm{mg} / \mathrm{kg}$ once a wk) for 4 wks & Inhibited prostate carcinogenesis [153] \\
\hline & $\begin{array}{l}\text { Nobiletin and auraptene } \\
\text { (plymethoxy-flavonoid } \\
\text { extracted from citrus fruits; } \\
\text { prenyloxycoumarin antioxidant } \\
\text { agent isolated from citrus fruits) }\end{array}$ & p.o. $(500 \mathrm{ppm})$ at $5 \mathrm{wks}$ of age for $15 \mathrm{wks}$ & $\begin{array}{l}\text { Nobiletin may be valuable for prostate } \\
\text { cancer prevention [154] }\end{array}$ \\
\hline & $\begin{array}{c}\text { Pioglitazone } \\
\text { (peroxisome proliferator- } \\
\text { activated receptor } \gamma \text { agonist) }\end{array}$ & p.o. $(0.1$ and $5 \mathrm{mg} / \mathrm{kg}$ ) 5 times $/$ wk for 8 wks & Suppressed prostate carcinogenesis [28] \\
\hline & $\begin{array}{l}\text { Pomegranate fruit juice and } \\
\text { ellagic acid } \\
\text { (polyphenol) }\end{array}$ & $\begin{array}{l}\text { p.o. (0.1\% or } 1 \% \text { ellagic acid ) or DW ( } 5 \% \text { pomegranate juice) for } \\
\qquad 10 \mathrm{wks}\end{array}$ & $\begin{array}{l}\text { Suppressed the progression of prostate } \\
\text { carcinogenesis ([29] }\end{array}$ \\
\hline & $\begin{array}{l}\text { Raloxifene and nimesulide } \\
\text { (Selective estrogen receptor }\end{array}$ & $\begin{array}{l}\text { s.c. }(5 \mathrm{mg} / \mathrm{kg} \text { raloxifene at } 5 \text { wks of for } 90 \text { days) or p.o. ( } 400 \\
\text { ppm/diet nimesulide) + s.c. ( } 5 \text { or } 10 \mathrm{mg} / \mathrm{kg} \text { raloxifene) for } 90\end{array}$ & $\begin{array}{l}\text { Raloxifene inhibited prostate tumor } \\
\text { development, but not nimesulide [155] }\end{array}$ \\
\hline
\end{tabular}




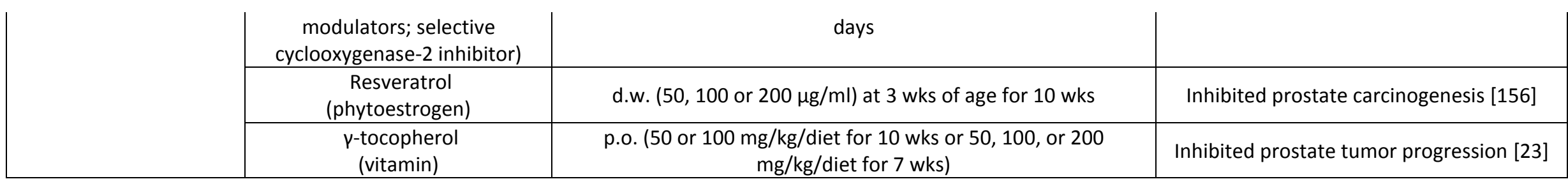

p.o.: per os; wks: weeks; d.w.: drinking water; s.c.: subcutaneous injection 
Seminal vesicle

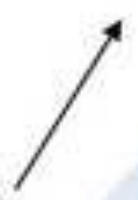

Urinary

bladder

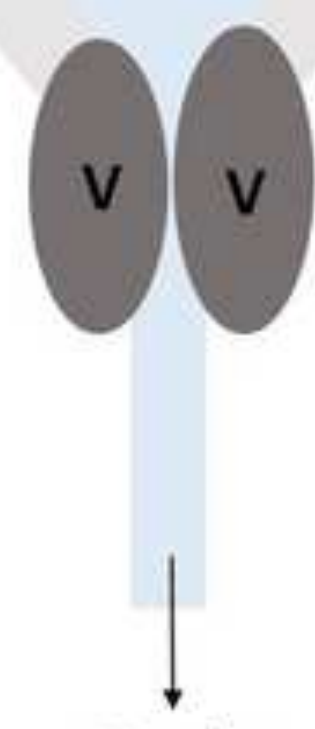

Urethra
Seminal vesicle

Urinary

bladder

DORSAL VIEW
Seminal vesicle

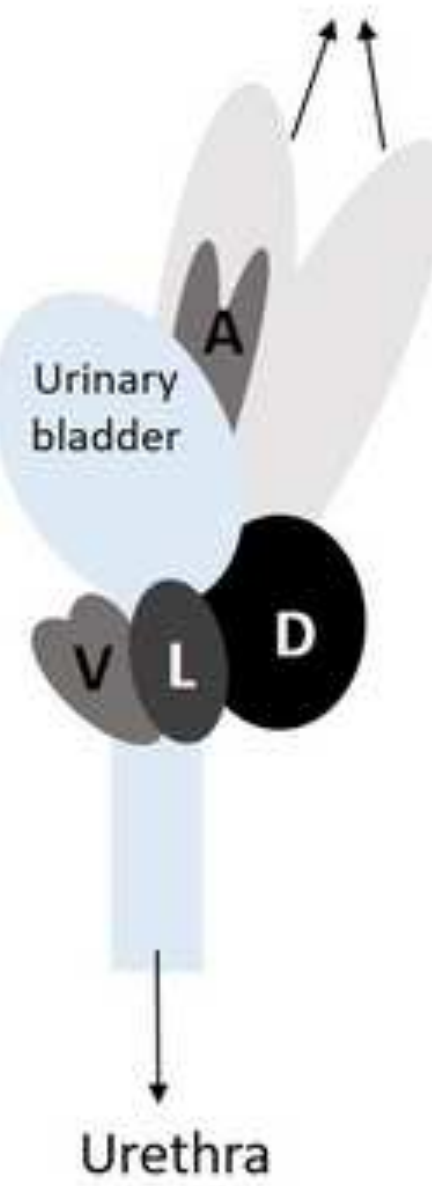

LATERAL VIEW

Urethra

\section{VENTRAL VIEW}
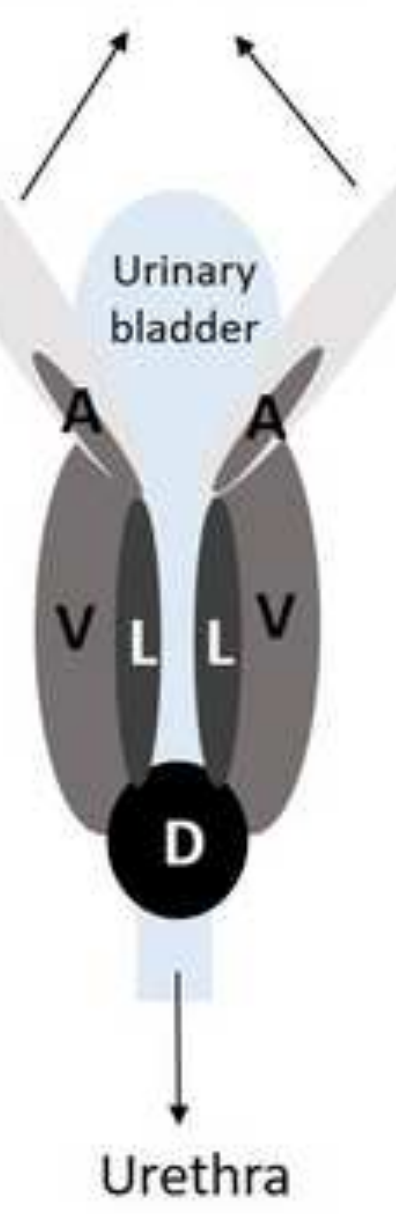
Click here to download high resolution image
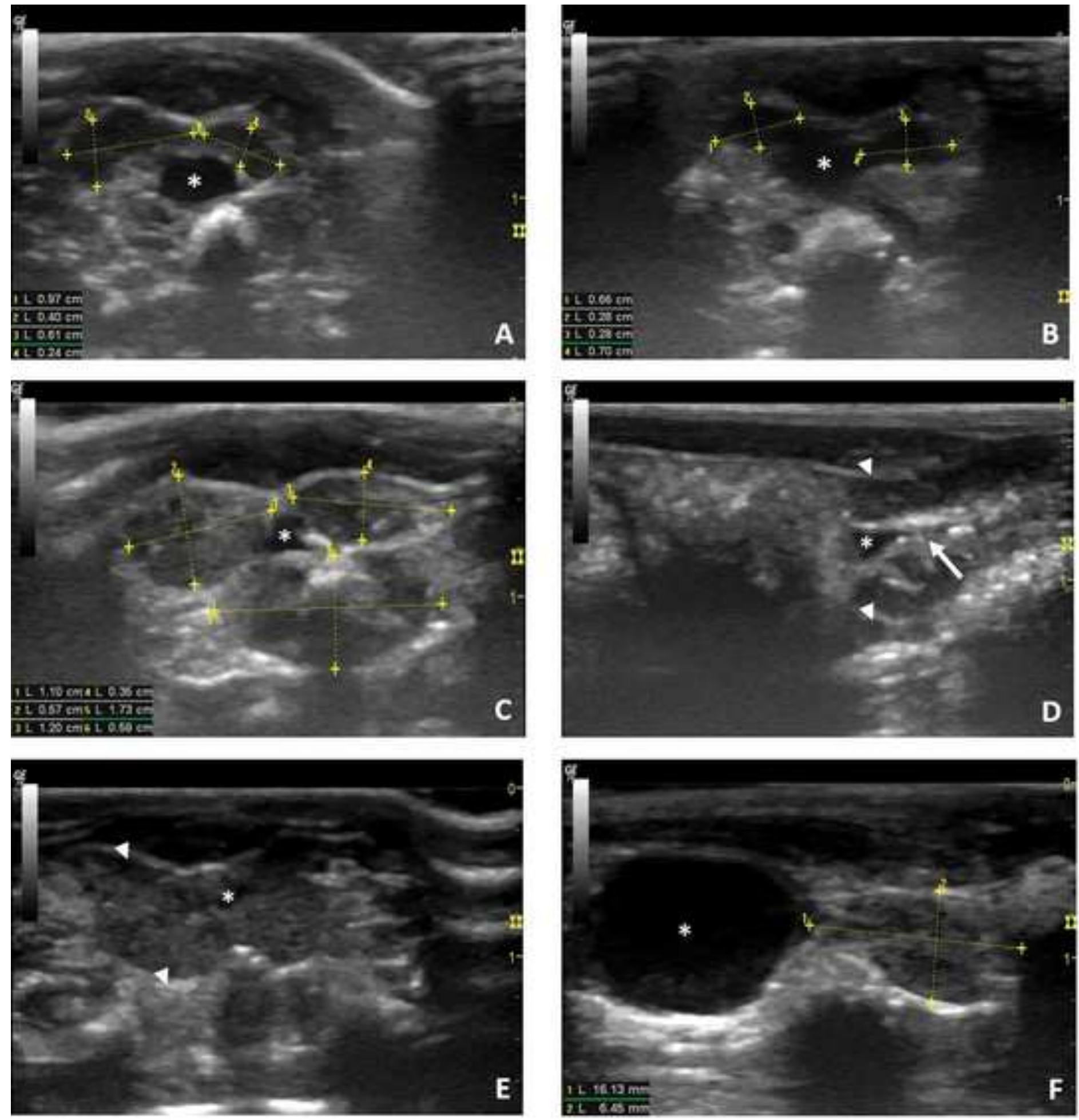
Click here to download high resolution image
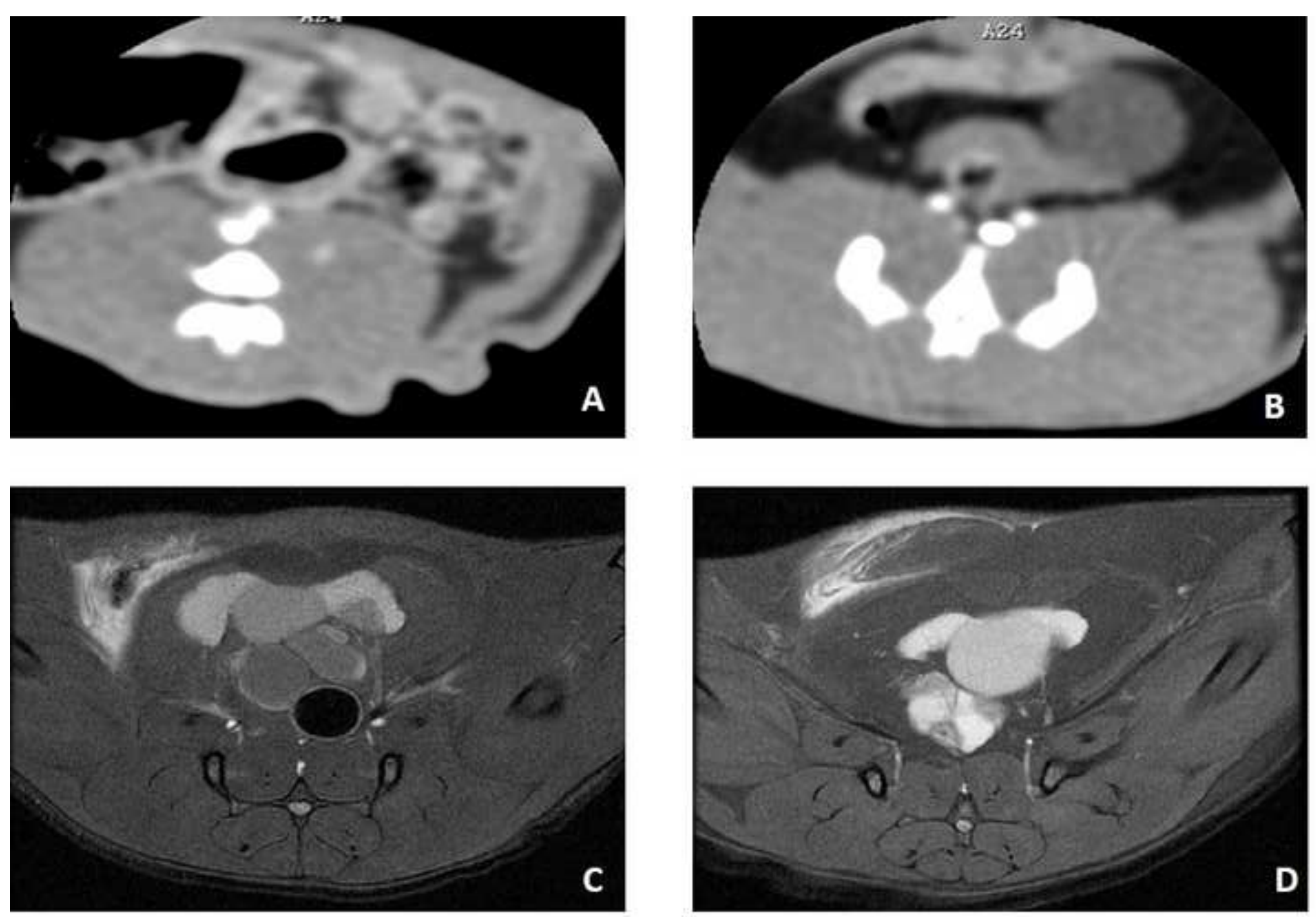


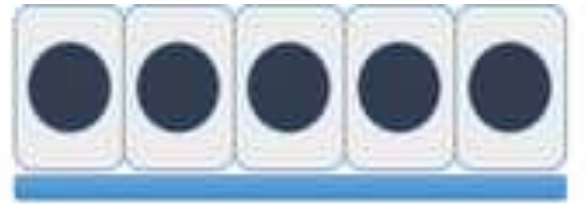

Non-neoplastic ("normal") cell

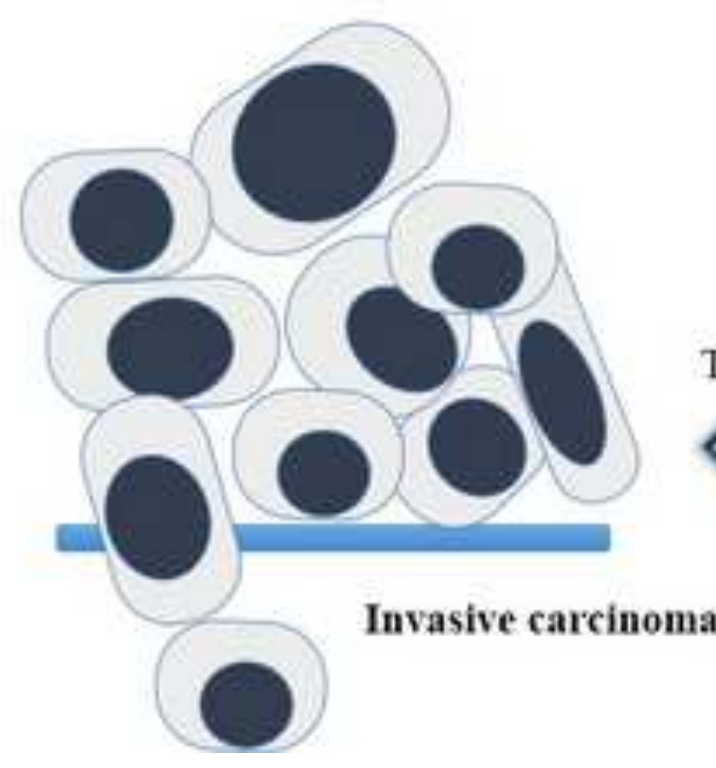

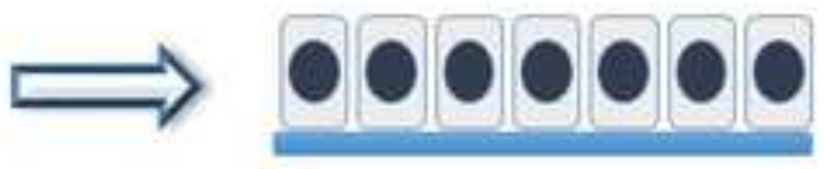

Flutamide

Testosterone

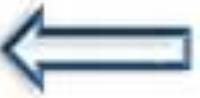

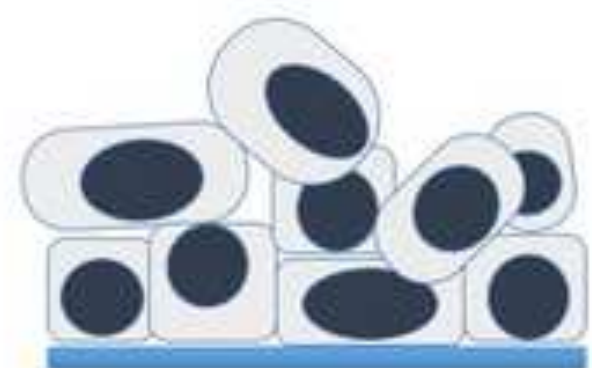

Carcinoma in situ

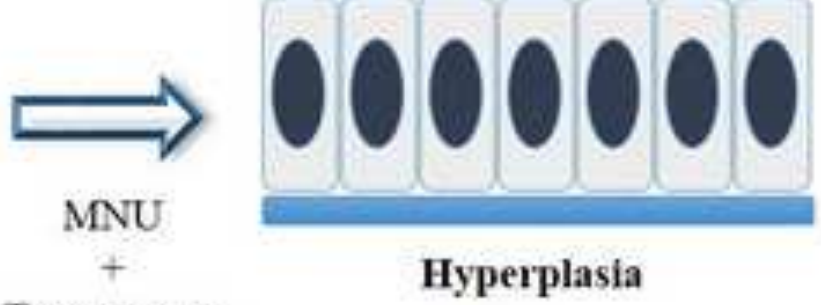

Testosterone

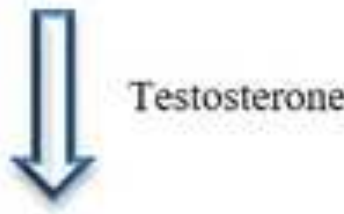

Testosterone
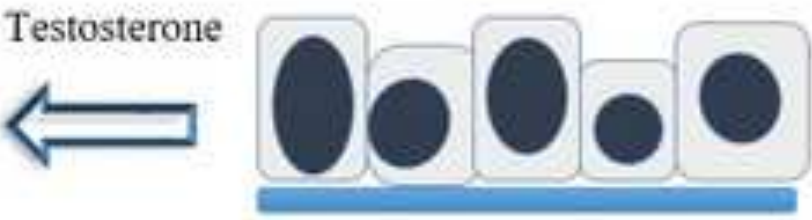

Dysplasia 